\title{
ANALISIS TINGKAT HARAPAN DAN KEPUASAN TERHADAP KUALITAS PELAYANAN PENYELENGGARAAN DIKLAT TEKNIS FUNGSIONAL GURU TINGKAT MADYA IPS MADRASAH TSANAWIYAH
}

\author{
Aminullah \\ Pusdiklat Tenaga Teknis Pendidikan dan Keagamaan \\ email: aminullahpusdiklat@yahoo.com
}

\begin{abstract}
ABSTRAK
Tujuan penelitian ini adalah untuk mengetahui penilaian peserta Diklat, apa saja yang belum terpenuhi terhadap penyelenggaraan diklat, untuk menganalisis faktor-faktor penentu tingkat harapan dan kepuasan peserta diklat terhadap penyelenggaraan diklat. Metode yang dipergunakan dalam penelitian ini adalah deskriptif kualitatif dengan pendekatan Importance Performance Analysis (IPA), dengan jumlah responden 60 peserta diklat teknis fungsional guru tingkat madya IPS MTs. Hasil penelitian sebagai berikut (1) penilaian peserta mengenai kualitas pelayanan penyelenggaraan diklat adalah (a) kinerja yang diberikan pihak penyelenggara belum sesuai dengan tingkat perioritas harapan peserta diklat dengan nilai rata-rata berada di antara 1,10 sampai dengan 2,95, (b) dilihat dari tingkat harapan dan tingkat kepuasan terdapat kesesuaian dengan nilai rata-rata 68,19\% sampai dengan $81,73 \%$, berarti kinerjanya sudah baik tetapi dalam pelaksanaan belum sepenuhnya sesuai dengan skala perioritas dari harapan peserta Diklat dan masih ada kinerja yang perlu ditingkatkan yakni pada variabel responsivenees (kesigapan). (2) Faktor-faktor penentu tingkat harapan dan kepuasan peserta terhadap kualitas pelayanan penyelenggaraan diklat sebagai berikut: (a) Faktor menempati janji melaksanakan pelayanan yang dijanjikan dengan tepat dan terpercaya (variabel reliability) dengan nilai rata-rata 2,95 dan (b) Faktor pengetahuan dan kemampuan widyaiswara untuk menimbulkan kepercayaan dan keyakinan dari peserta (variabel assurance) dengan nilai rata-rata 2,74.
\end{abstract}

Kata Kunci: Analisis, harapan, kepuasan, dan kualitas pelayanan.

\section{ABSTRACT}

The purpose of this study is to know the evaluation of the participants of the Diklat (education and training), what has not been fulfilled yet in the organization of the Diklat program, to analyze the determinants of the 
level of expectations and satisfaction of the Diklat's participants regarding the organization of the Diklat. The method used in this study is descriptivequalitative with Importance-Performance Analysis (IPA) approach that involved 60 respondents of the Diklat's participants of social science teachers of Islamic Junior High School (MTs). The result of the study is (1) the participant evaluated that the quality of service in the organization of the Diklat is (a) the performance given by the organizers is not in accordance with the level of expectations of the Diklat's participants with an average score between 1.10 to 2.95, (b) based on the level of expectation and satisfaction against the services given, with an average score of $68.19 \%$ to $81.73 \%$, it means that the organizers' performance is good but the organization is not fully in accordance with the priority scale of the expectations of the Diklat's participants and therefore needs to be improved that is in the aspect of responsiveness (alertness). (2) the determinants of the level of expectations and satisfaction of participants on the service quality of Diklat (the education and training implementation) as follows: (a) factors keep the promise of carrying out the promised service appropriately and reliably (reliability variable) with an average value of 2.95 and (b) knowledge factors and the ability of the Widyaiswara to generate trust and assurance from the participants (assurance variable) with an average value of 2.74.

Keywords: Analysis; Expectation; Satisfaction; and Service Quality.

\section{PENDAHULUAN}

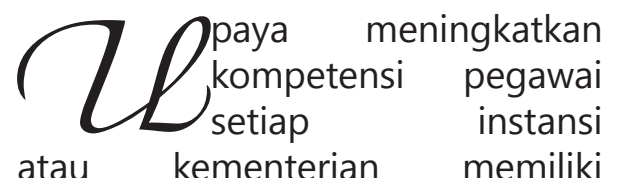

lembaga pendidikan dan pelatihan (Diklat). Peran lembaga bertujuan untuk meningkatkan dan mengembangkan dapat kompetensi setiap instantasi sesuai dengan kebutuhan serta tugas dan fungsinya. Berkaitan dengan hal itu, Kementerian Agama menyusun Peraturan Menteri Agama (PMA) No. 75 tahun 2015 tentang Penyelenggaraan Diklat. Pasal 1 ayat 1 PMA tersebut menyatakan bahwa pendidikan dan pelatihan yang selanjutnya disebut Diklat adalah penyelenggaraan pembelajaran dan pelatihan dalam rangka mengembangkan kompetensi pegawai sesuai persyaratan jabatan masing-masing pada Kementerian Agama yang dilaksanakan paling sedikit 40 (empat puluh) jam pelajaran, dengan durasi tiap jam pelajaran adalah 45 (empat puluh lima) menit

Selanjutnya pasal 1 ayat 23 dinyatakan bahwa Penyelenggara Diklat adalah Aparatur Sipil Negara (ASN) yang bertugas pada lembaga diklat pemerintah yang secara fungsional melaksanakan tugas-tugas untuk mendukung 
penyelenggaraan diklat sesuai pedoman yang ditetapkan oleh instansi teknis.

Pada pada pasal 1 ayat 27 dinyatakan bahwa Pusdiklat Tenaga Teknis Pendidikan dan Keagamaan adalah Lembaga Diklat pada Kementerian Agama yang mempunyai tugas menyelenggarakan Diklat Tenaga Teknis Pendidikan dan Keagamaan, mengembangkan sistem kediklatan Tenaga Teknis Pendidikan dan Keagamaan, dan pembinaan unit pelaksana teknis dibidang pelaksanaan Diklat Tenaga Teknis Pendidikan dan Keagamaan.

\section{Tujuan}

Diklat seperti tercantum pada pasal 2 adalah: (a) meningkatkan pengetahuan, keahlian, keterampilan dan sikap pegawai untuk dapat melaksanakan tugas jabatan secara profesional yang dilandasi kepribadian dan kode etik pegawai sesuai dengan kebutuhan Kementerian Agama; (b) menciptakan aparatur yang mampu berperan sebagai pembaru dan perekat persatuan dan kesatuan bangsa; (c) memantapkan orientasi sikap dan semangat pengabdian yang berorientasi kepada pelayanan, pengayoman, dan pemberdayaan masyarakat; dan (d) menciptakan pegawai yang berkualitas, profesional berintegritas, dan bertanggung jawab.

Memperhatikan pasal 2 tersebut, maka keberadaan Pusdiklat Tenaga
Teknis Pendidikan dan Keagamaan sangat strategis terutama dalam butir (a) meningkatkan pengetahuan, keahlian, ketrampilan dan sikap pegawai dan butir (c) memantapkan orientasi sikap dan semangat pengabdian yang berorientasi kepada pelayanan, pengayoman, dan pemberdayaan masyarakat. Menggaris bawahi orientasi semangat pengabdian dan kepada pelayanan itu, maka dengan demikian Pusdiklat Tenaga Teknis dituntut untuk memiliki kinerja yang baik dan memuaskan.

Hasil studi pendahuluan (2017) dengan wawancara peserta diperoleh fakta, bahwa adanya masalah atau ketidaksesuaian sebagai berikut: (1) adanya perbedaan antara harapan peserta dan pesepsi kinerja penyelenggara kediklatan; (2) kesenjangan antara persepsi kinerja dan spesifikasi kualitas pelayanan; (3) kesenjangan antara spesifikasi kualitas pelayanan dan penyampaian pelayanan; (4) kesenjangan penyampaian pelayanan dan komunikasi eksternal; dan (5) adanya perbedaan antara pelayanan yang dialami dan pelayanan yang diharapkan.

Langkah untuk melihat ketidaksesuaikan tersebut adalah perlu dilakukan penelitian yang bertujuan pemecahan masalah dan mendapat jalan keluar (problem solving). Oleh sebab itu, peneliti tertarik untuk melakukan penelitian dengan judul "Analisis Tingkat Harapan dan Kepuasan terhadap 
Penyelenggaraan Diklat Teknis Fungsional Guru IPS MTs Tingkat Madya Pusdiklat Tenaga Teknis Pendidikan dan Keagamaan Tahun 2018".

Berdasarkan batasan masalah tersebut, maka masalah pokok yang ingin dijawab dalam penelitian ini adalah sebagai berikut:

1. Bagaimana penilaian peserta mengenai kualitas pelayanan yang diberikan terhadap penyelenggaraan diklat?

2. Faktor-faktor apa yang menjadi penentu tingkat harapan dan kepuasan peserta terhadap Penyelenggaraan diklat?

Adapun tujuan dari penelitian ini adalah:

1. Untuk mengetahui penilaian peserta, aspek apa saja yang belum terpenuhi dalam penyelenggaraan diklat teknis fungsional guru IPS MTs tingkat madya Pusdiklat Tenaga Teknis Pendidikan dan Keagamaan;

2. Untuk menganalisis faktorfaktor apa yang menjadi penentu tingkat harapan dan kepuasan peserta Diklat terhadap Penyelenggaraan Diklat.

Manfaat yang diharapkan dalam penelitian ini adalah sebagai berikut :

1. Bagi Pusdiklat Tenaga Teknis Pendidikan dan Keagamaan memperoleh gambaran dan informasi yang berguna bagi Pusdiklat Tenaga Teknis Pendidikan dan Keagamaan dalam melakukan kebijakan dan strategi yang berkaitan dengan kualitas pelayanan dan kepuasan peserta diklat.

2. Bagi penulis, dapat meningkatkan kualitas layanan pembelajaran.

3. Bagi peneliti lain sebagai bahan referensi dan informasi dalam melakukan penelitian lebih lanjut terutama yang berhubungan dengan kualitas pelayanan dan kepuasan peserta diklat/konsumen.

\section{Kajian teoritik}

\section{Teori Analisis}

Analisis diartikan sebagai penyelidikan terhadap suatu peristiwa (karangan, perbuatan) untuk mengetahui keadaan yang sebenarnya (sabab-musabab, duduk perkaranya) (KBBI, 1996: 779).

Analisis adalah kegiatan berfikir untuk menguraikan sesuatu keseluruhan menjadi komponen sehingga dapat mengenal tandatanda komponen, hubungannya satu sama lain dan fungsi masingmasing dalam satu keseluruhan yang terpadu (Komaruddin, 2001: 53).

Analisis adalah memecahkan atau menguraikan suatu unit menjadi berbagai unit terkecil (Harahap, 2004:189). Analisis 
adalah aktivitas yang memuat sejumlah kegiatan, seperti mengurai, membedakan, memilah sesuatu untuk digolongkan dan dikelompokan kembali menurut kriteria tertentu kemudian dicari kaitannya dan ditafsirkan maknanya (Wiradi, 2006: 24).

Analisis pada penelitian ini yaitu aktivitas yang memuat sejumlah kegiatan, seperti mengurai, membedakan, memilah sesuatu untuk digolongkan dan dikelompokan kembali menurut kreteria tertentu kemudian dicari kaitannya dan ditafsirkan maknanya, atau merangking berbagai elemen dari kualitas pelayanan yang diterima oleh responden terhadap penyelenggaraan diklat teknis fungsional guru IPS MTs Pusdiklat Tenaga Teknis Pendidikan dan Keagamaan (selanjutnya disebut peserta Diklat).

2. Teori Harapan

Antin Yohana (2009: 26), menyatakan bahwa harapan pelanggan merupakan keyakinan pelanggan sebelum mencoba atau membeli suatu produk yang dijadikan standar atau acuan dalam menilai kinerja produk tersebut.

Victor H. Vroom, dalam bukunya yang berjudul "Work And Motivation" mengetengahkan suatu teori yang disebutnya sebagai "Teori Harapan". Menurut teori ini, motivasi merupakan akibat suatu hasil yang ingin dicapai oleh seorang dan perkiraan yang bersangkutan bahwa tindakannya akan mengarah kepada hasil yang diinginkannya itu. Artinya, apabila seseorang sangat menginginkan sesuatu, dan jalan tampaknya terbuka untuk memperolehnya, yang bersangkutan akan berupaya mendapatkannya.

Selanjutnya Hill (1992: 45) mendefenisikan harapan adalah sesuatu yang akan timbul saat konsumen memerlukan suatu barang atau jasa. Di saat konsumen belum memerlukan barang atau jasa, maka konsumen tidak akan mengharapkan sesuatu dari barang atau jasa. Harapan apa yang konsumen pikirkan harus disediakan oleh penyedia jasa. Akan tetapi, harapan bukan merupakan prediksi dari apa yang akan disediakan oleh penyedia jasa.

Allen (1998) menyebutkan teori harapan yang dikembangkan oleh Vroom yang dikenal dengan Vroom's Expectancy Model yaitu bahwa pada umumnya manusia memilih salah satu di antara beberapa alternatif perilaku karena manusia tersebut melakukan antisipasi yang secara khusus akan membawa seseorang kepada hasil sesuatu yang diinginkan dan perilaku yang akan membawanya kepada sesuatu yang tidak diinginkan. Terkait hal ini harapan (expectancy) dipercaya sebagai sesuatu yang diinginkan untuk mendapatkan hasil yang maksimal.

J. Lopez dalam Averill, (2009:487), menyatakan bahwa 
harapan merupakan istilah yang telah banyak dideskripsikan oleh para ahli dalam bidang psikologi. Harapan juga sebagai emosi yang diarahkan oleh kognisi dan dipengaruhi oleh kondisi lingkungan. Harapan sebagai keinginan untuk mencapai tujuan. Kreitner dalam Erly Suandy (2003:300) mengemukan bahwa teori harapan berpegang pada motivasi untuk berperilaku yang mengahasilkan kombinasi keinginan yang diharapkan sebagai hasil.

Berdasar beberapa defenisi para ahli tentang teori harapan tersebut, maka bisa disimpulkan bahwa harapan adalah keinginan untuk mendapatkan hasil yang maksimal. Harapan peserta sangat berkaitan erat dengan kualitas pelayanan, Contoh: apabila pelayanan yang diterima atau dirasakan sesuai dengan yang diharapkan, maka kualitas pelayanan dipersepsikan baik dan memuaskan, jika pelayanan yang diterima melebihi harapan pelanggan, maka kualitas dipersepsikan sebagai kualitas yang ideal, sedangkan bila pelayanan yang diterima lebih rendah dari yang diharapkan, maka kualitas pelayanan dipersepsikan sebagai buruk. Sehingga pelanggan tidak berminat lagi pada penyedia pelayanan, sebaliknya bila pelayanan yang dialami memenuhi atau melebihi harapan, mereka akan menggunakan penyedia pelayanan itu lagi.
Menurut Horovitz (2000: 3-7), persepsi dipengaruhi oleh tiga faktor, yakni:

a. Faktor psikologis

Faktor psikologis akan membuat perubahan dalam persepsi konsumen. Perubahan yang dimaksudkan termasuk memori, pengetahuan, kepercayaan, nilai-nilai yang dianggap konsumen penting dan berguna.

b. Faktor Fisik

Faktor fisik akan mengubah persepsi konsumen melalui apa yang konsumen lihat dan rasakan. Faktor fisik dapat memperkuat atau malah menghancurkan persepsi konsumen terhadap kualitas layanan yang diberikan oleh perusahaan.

c. Image yang terbentuk

Image yang dimaksud disini adalah image konsumen terhadap perusahaan atau produk. Lebih lanjut menurut Kotler, Bowen \& Makens (1999:263), ketika terjadi persaingan antara 2 merek produk yang sama, konsumen bisa melihat perbedaan melalui image dari perusahaan atau merek itu sendiri.

Oleh karena itu perusahaan harus mampu menciptakan image yang akan membedakannya dari pesaing. Menciptakan image yang kuat 
dan berbeda memerlukan kreativitas dan kerja keras. Image yang sudah tercipta harus didukung oleh segala sesuatu yang dilakukan dan dikatakan oleh perusahaan.

Antin Yohana (2009:26) menyatakan bahwa faktor yang mempengaruhi harapan pelanggan dan cara-cara yang dapat dilakukan pemasar jasa untuk mempengaruhi pelanggan, antara lain :

d. Enduring Service Intensifier

Faktor ini meliputi harapan yang disebabkan oleh orang lain dan filsofi pribadi seseorang mengenai jasa. Seorang pelanggan akan mengharapkan bahwa ia seharusnya juga dilayani dengan baik apabila pelanggan yang lainnya dilayani dengan baik oleh penyedia jasa. Cara yang dapat dilakukan pemasar jasa, yaitu menggunakan riset pasar untuk menentukan sumber dari derived service expectations dan kebutuhan mereka.

\section{e. Transitory Service Intensifier}

Faktor ini merupakan faktor individual yang bersifat sementara (jangka pendek) yang meningkatkan sensivitas pelanggan terhadap jasa, yaitu situasi darurat pada saat pelanggan sangat membutuhkan jasa dan jasa terakhir yang dikonsumsi pelanggan dapat pula menjadi acuannya untuk menentukan baik buruknya jasa berikutnya. Cara yang dapat dilakukan pemasar jasa, yaitu meningkatkan penyampaian jasa selama periode puncak atau dalam situasi darurat.

\section{f. Personal Need}

Pengharapan konsumen dipengaruhi oleh kebutuhan pribadi yang biasanya tergantung pada karakteristik dan keadaan pribadi, sehingga memiliki pengaruh yang kuat. Cara yang dilakukan pemasar jasa, yaitu mendidik para pelanggan sebagaimana jasa mengarah pada kebutuhan mereka.

g. Past Experience

Pengalaman masa lampau meliputi hal-hal yang telah dipelajari atau diketahui pelanggan, yang lupa berpengaruh terhadap konsumen. Harapan pelanggan dari waktu ke waktu berkembang, seiring dengan semakin banyaknya informasi yang diterima pelanggan serta semakin bertambahnya pengalaman pelanggan. Cara yang dilakukan pemasar jasa, yaitu memanfaatkan riset pemasaran untuk mengetahui pengalaman sebelumnya yang dialami pelanggan dengan jasa serupa. 


\section{h. Word-of-Mouth}

Pengaruh yang timbul karena apa yang didengar oleh konsumen dari konsumen lain, dan mereka cenderung mempercayainya sehingga pengaruh ini bersifat potensial. Word-of-mouth ini biasanya cepat diterima oleh pelanggan karena yang menyampaikan adalah mereka yang dapat dipercayainya, seperti pakar, teman, keluarga, dan publikasi media masa. Selain itu, itu word-of-mouth juga cepat diterima sebagai referensi karena pelanggan jasa biasanya sulit mengevaluasi jasa yang belum dirasakannya sendiri.

Selanjutnaya Antin Yohana menyatakan bahwa pada dasarnya ada dua tingkatan harapan pelanggan, yaitu:

\section{Desired Expectation}

Harapan ini mencerminkan apa yang harus dilakukan oleh suatu lembaga kepada pelanggannya. Yaitu suatu kombinasi dari apa yang "dapat" dilakukan dan apa yang "harus" dilakukan kepada pelanggannya.

\section{Dequate Expactation}

Kepuasan terpenuhi walau tidak maksimal. Dengan demikian harapan pelanggan sebenarnya mempunyai zona yang terbentuk antara desired dan adequate expectation, pelanggan akan sangat puas atau delighted apabila desired expectation-nya terpenuhi.
Berdasarkan beberapa faktor yang mempengaruhi teori harapan tersebut, maka dapat disimpulkan bahwa harapan itu adalah suatu yang diinginkan oleh seseorang, sehingga menimbulkan motivasi untuk mencapai keinginan tersebut. Apabila apa yang diharapkan tercapai, maka orang tersebut merasa puas, tapi apabila harapan tidak tercapai, maka orang tersebut tidak puas.

John A. Martila and John C. Jam dalam J. Supranto, (2003:402), dalam Importance Performance Analysis memberikan ukuran untuk harapan yaitu: 5 kualitas jasa/pelayanan karena dirasakan adanya dimensi mutu yaitu :

1. Tangible (berwujud): dimensi mutu pelayanan yang meliputi penampilan fisik dari fasilitas, peralatan, karyawan dan peralatan komunikasi.

2. Realibility (keandalan): dimensi mutu pelayanan yang berupa kemampuan untuk memberikan pelayanan/jasa yang telah dijanjikan secara konsisten dan dapat diandalkan (akurat).

3. Responsiveness (cepat tanggap): dimensi mutu pelayanan tentang kemauan untuk membantu pelanggan (pasien) dan menyediakan jasa/pelayanan yang cepat dan tepat.

4. Assurance (kepastian): dimensi mutu pelayanan yang mencakup pengetahuan 
dan keramah-tamahan para karyawan dan kemampuan mereka untuk menimbulkan kepercayaan dan keyakinan, kesopanan dan sifat dapat dipercaya yang dimiliki para staf, bebas dari bahaya, risiko atau keragu-raguan.

5. Empaty (empati): dimensi mutu pelayanan yang meliputi pemahaman pemberian perhatian secara individual kepada pelanggan, kemudahan dalam melakukan komunikasi yang baik, dan memahami kebutuhan pelanggan.

Berdasar uraian tersebut, harapan peserta dapat diukur dengan mutu layanan yang meliputi: Tangible, Realibility, Responsiveness, Assurance, Empaty.

3. Teori Kepuasan

$$
\text { J. Supranto }
$$
mengatakan bahwa "kepuasan adalah tingkat perasaan seseorang setelah membandingkan kinerja/ hasil yang dirasakan dengan harapannya". Jadi, tingkat kepuasan merupakan fungsi harapan, maka pelanggan akan kecewa bila kinerjanya tidak sesuai dengan harapan, dan sebaliknya pelanggan akan sangat puas, bila kinerjanya melebihi harapan. Harapan pelanggan dapat di bentuk oleh pengalaman masa lampau, komentar dari kerabatnya serta janji dan informasi pemasaran atau iklan dan saingannya.
Wexly dan Yuli dalam dalam Shobarudin (2005:16), mendefenisikan kepuasan adalah cara merasakan mengennai sesuatu. Kepuasan dipengaruhi oleh beberapa aspek Pelanggan yang merasa puas akan setia lebih lama, kurang sensitive terhadap harga dan memberi komentar yang baik tentang organisasi/ perusahaan. Membeli berkali-kali dan mengajak orang lain untuk membali. Untuk menciptakan kepuasan pelanggan, organisasi/ perusahaan harus menciptakan dan mengelola suatu sistim untuk memperoleh pelanggan yang lebih banyak dan kemampuan untuk mempertahankan pelanggannya.

Antin Yohana (2009:28), menyatakan bahwa kepuasan pelanggan merupakan evaluasi purnabeli dimana alternatif yang dipilih sekurang-kurangnya sama atau melampaui harapan pelanggan, ketidakpuasan muncul apabila hasil tidak memenuhi harapan.

Sedangkan menurut Kotler dalam Tjiptono (1994), kepuasan pelanggan adalah tingkat perasaan seseorang setelah membandingkan kinerja atau hasil yang ia rasakan dengan harapannya. Harapan konsumen mempunyai peran yang besar dalam membentuk kepuasan konsumen. Terkait konteks kepuasan konsumen, harapan merupakan perkiraan atau keyakinan konsumen tentang apa yang akan diterimanya. Sedangkan 
kinerja yang dirasakan adalah persepsi pelanggan terhadap apa yang ia terima.

Kotler dalam Tjiptono (1994:42) mengemukakan bahwa untuk mengukur kepuasan pelanggan, dapat digunakan beberapa metode, yaitu : (1) Sistem keluhan dan saran; dan (2) Survei kepuasan pelanggan.

\section{Pengukuran}

kepuasan pelanggan melalui metode ini dapat dilakukan dengan berbagai cara, diantaranya: (a) Directly reported satisfaction yakni pengukuran langsung dengan pertanyaanpertanyaan yang disampaikan kepada pelanggan tentang tingkat kepuasan pelanggan terhadap pelayanan; (b)Deriveddissatisfaction yakni pengukuran yang dilakukan dengan cara mengajukan pertanyaan tentang seberapa besar harapan dan hasil dari kinerja pelayanan yang telah dirasakan pelanggan; (c) Problem analysis yakni pengukuran kepuasan yang dilakukan dengan cara meminta responden untuk menuliskan masalah yang berkaitan dengan pelayanan yang telah diberikan beserta menuliskan saran-saran untuk perbaikan dalam pelayanan; (d) Importance-performance analysis yakni pengukuran kepuasan yang dilakukan dengan cara meminta responden untuk merangking berbagai elemen dari pelayanan yang ditawarkan kinerja pelayanan masing-masing elemen; (e) Ghost shopping yaitu metode yang dilakukan dengan cara mempekerjakan beberapa orang untuk berperan atau bersikap sebagai pelanggan dengan tujuan untuk melihat kekurangan atau kelebihan dari pelayanan; (f) Lost customer analysis yang dilakukan dengan cara pemberi pelayanan menghubungi pelanggan yang berhenti atau pindah ke tempat pelayanan lain dan memantau angka kehilangan pelanggan yang menunjukkan kelemahan dalam memuaskan pelanggan.

J. Supranto (2004:397), mengutip Philip Kotler, mengemukakan metode mengukur kepuasan pelanggan sebagai berikut: (1) Directly report satisfacation yaitu menanyakan tingkat kepuasan konsumen atas pelayanan perusahaan baik secara keseluruhan maupun secara kusus, yang akan memperoleh jawaban mulai sangat tidak puas sampai dengan sangat puas; yang kemudian disajikan dalam bentuk data diagram; (2) Derived dissatisfaction yaitu dengan meminta partifasi pelanggan untuk menilai kualitas pelayanann saat ini dan ditanyakan bagaimana seharusnya menurut mereka; (3) Problem analysis yaitu menanyakan apa yang menjadi masalah pelanggan dalam mendapatkan pelayanan sekaligus meminta usulan mereka sebagai bahan koreksi di masa mendatang; dan (4) Importance/performance ratings yaitu menanyakan para pelanggan mengenai tingkat 
kepentingan tiap pelayanan dan bagaimana perusahaan menyajikan tiap pelayanan tersebut.

\section{Teori Kualitas Pelayanan}

$$
\text { J. Supanto }
$$
mendefenisikan kualitas pelayanan adalahsesuatuyang bersifatabstrak, sukar untuk diukur serta sangat subyektif sifatnya. Selanjutnya American Society for Quality Control, yang dikutip oleh Lupiyoadi (2001:144), mendefinisikan kualitas adalah keseluruhan ciri-ciri dan karakteristik-karakteristik dari suatu produk/jasa dalam hal kemampuannya untuk memenuhi kebutuhan-kebutuhan yang telah ditentukan bersifat laten.

Chistoper H. Loveklok (1992:229), mendefinisikan kualitas pelayanan sebagai berikut; Quality is degree of excellence intended, and the control of variability in achieving that excellent, in meeting the customer requirement (kualitas adalah tingkat mutu yang baik sesuai dengan yang diharapkan, dan pengawasan untuk mencapai mutu yang baik untuk dapat memenuhi keinginan konsumen). Ernon A. Musselman (1987:294), mendefenisikan kualitas pelayanan sebagai customer service and quality levelto is the degree to which a service meets the specifications of management and the expections of customers (sebagai tingkat pelayanan yang diberikan oleh manajemen memenuhi harapan konsumen.
Jika dilihat dari Total Quality Management (TQM), yang dikutip oleh Tjiptono (2001: 51) kualitas dipandang secara lebih luas, tidak hanya aspek hasil saja yang ditinjau, tetapi meliputi suatu kondisi dinamis yang berhubungan dengan produk, jasa, manusia, proses dan lingkungan yang memenuhi atau melebihi harapan.

Selanjutnya Parasuraman (1984:84) mendefenisikan kualitas pelayanan yaitu: ada dua faktor utama yang mempengaruhi kualitas pelayanan, yaitu expected service, dan perceived service, yang menjelaskan bahwa apabila pelayanan yang diterima atau dirasakan sesuai dengan yang diharapkan, maka kualitas pelayanan dipersepsikan baik dan memuaskan, jika pelayanan yang diterima melebihi harapan pelanggan, maka kualitas dipersepsikan sebagai kualitas yang ideal, sedangkan bila pelayanan yang diterima lebih rendah dari yang diharapkan, maka kualitas pelayanan dipersepsikan sebagai buruk. Sehingga pelanggan tidak berminat lagi pada penyedia pelayanan, sebaliknya bila pelayanan yang dialami memenuhi atau melebihi harapan, mereka akan menggunakan penyedia pelayanan itu lagi.

Berdasar atas beberapa definisi tersebut, maka dapat disimpulkan bahwa kualitas pelayanan sangat erat kaitan dengan harapan pelanggan, missal: suatu pelayanan 
yang diterima atau dirasakan sesuai dengan yang diharapkan, maka kualitas pelayanan dipersepsikan baik dan memuaskan, jika suatu pelayanan yang diterima melebihi harapan pelanggan, maka kualitas dipersepsikan sebagai kualitas yang ideal, sedangkan bila pelayanan yang diterima lebih rendah dari yang diharapkan, maka kualitas pelayanan dipersepsikan sebagai buruk. Sehingga pelanggan tidak berminat lagi pada penyedia pelayanan, sebaliknya bila pelayanan yang dialami memenuhi atau melebihi harapan, mereka akan menggunakan penyedia pelayanan itu lagi.

Kualitas pelayanan merupakan tindakan seseorang kepada pihak lain melalui penyajian produk atau jasa sesuai dengan selera, harapan dan kebutuhan konsumen. Perusahaan dapat memberikan pelayanan yang sesuai dengan keinginan yang diharapkan konsumen, maka kualitas pelayanan perusahaan tersebut baik. Pelayanan yang baik tersebut akan memberikan dorongan kepada konsumen untuk melakukan pembelian ulang di perusahaan tersebut.

Antin Yohana (2009:32 ) menyatakan bahwa faktor-faktor yang mempengaruhi dimensi kualitas pelayanan pelanggan meliputi: (1) Kompetensi teknis terkait dengan ketrampilan, kemampuan dan penampilan petugas; (2) Akses terhadap pelayanan. Pelayanan yang tak terhalang oleh keadaan geografis, sosial, ekonomi, budaya, organisasi atau hambatan bahasa;

Efektivitas, menyangkut norma pelayanan dan petunjuk teknis sesuai standar yang ada; (4) Efisiensi, terkait dengan pemilihan intervensi yang cost effective, karena terbatasnya sumber daya pelayanan pelanggan; (5) Kontinuitas, pelayanan yang diberikan lengkap sesuai pelanggan yang dibutuhkan tanpa interupsi, berhenti atau mengulangi prosedur yang tak perlu; (6) Keamanan, berarti mengurangi resiko cedera, infeksi, efek samping dan bahaya lain yang berkaitan dengan pelayanan; (7) Hubungan antar manusia, berkaitan dengan interaksi antara petugas dengan pelanggan, manajer dan petugas, dan antara tim dengan masyarakat; (8) Kenyamanan, berkaitan dengan pelayanan yang tak berhubungan langsung dengan efektifitas klinis, tapi dapat mempengaruhi kepuasan pelanggan dan bersedianya untuk kembali ke fasilitas untuk memperoleh pelayanan berikutnya.

Sedangkan menurut Parasuman, Zeithaml dan Barry (1994:16), kualitas pelayanan merupakan konstruksi multidimensi, yang terdiri dari banyak atribut yang berbeda satu sama lain, yang meliputi: (1) Tangible (nyata/berwujud); (2) Reliability (keandalan); Responsiveness (cepat tanggap); (4) Competence (kompetensi); 
(5) Access (kemudahan); Courtesy (keramahan); Communication (komunikasi); (8) Credibility (kepercayaan); (9) Security (kemananan); dan (10) Understanding the customer (Pemahaman pelanggan).

Pada

perkembangan selanjutnya, dirasakan adanya dimensi kualitas pelayanan yang saling tumpang tindih satu dengan yang lainnya yang dikaitkan dengan kepuasan pelanggan. Selanjutnya oleh Parasuraman (2001: 26), dimensi-dimensi tersebut difokuskan menjadi 5 (lima) dimensi (ukuran) kualitas pelayanan karena dirasakan adanya dimensi mutu yang saling tumpang tindih, yaitu:

a. Tangible (berwujud), dimensi kualitas pelayanan yang meliputi penampilan fisik dari fasilitas, peralatan, karyawan dan peralatan komunikasi.

Tjiptono (2012: 175) menyatakan bahwa tangible berkenaan dengan penampilan fisik fasilitas layanan, peralatan/perlengkapan, sumber daya manusia, dan materi komunikasi perusahaan. Selanjutnya Parasuraman (2001: 32) mengatakan bahwa pengertian tangible dalam kualitas pelayanan adalah bentuk aktualisasi nyata secara fisik dapat terlihat atau digunakan oleh pegawai sesuai dengan penggunaan dan pemanfaatannya yang dapat dirasakan membantu pelayanan yang diterima oleh orang yang menginginkan pelayanan, sehingga puas atas pelayanan yang dirasakan, yang sekaligus menunjukkan prestasi kerja atas pemberian pelayanan yang diberikan.

Martul (2004:49) menyatakan bahwa kualitas pelayanan berupa kondisi fisik merupakan bentuk kualitas pelayanan nyata yang memberikan adanya apresiasi dan membentuk imej positif bagi setiap individu yang dilayaninya dan menjadi suatu penilaian dalam menentukan kemampuan dari pengembang pelayanan tersebut memanfaatkan segala kemampuannya untuk dilihat secara fisik, baik dalam menggunakan alat dan perlengkapan pelayanan, kemampuan menginovasi dan mengadopsi teknologi, dan menunjukkan suatu performance tampilan yang cakap, berwibawa dan memiliki integritas yang tinggi sebagai suatu wujud dari prestasi kerja yang ditunjukkan kepada orang yang mendapat pelayanan.

b. Realibility (keandalan), dimensi mutu pelayanan yang berupa kemampuan untuk memberikan pelayanan /jasa yang telah dijanjikan secara konsisten dan dapat 
diandalkan (akurat).

Tjiptono,

(2012:174), menyatakan bahwa reability "Namun, bila konsultan mewujudkan apa yang diharapkan klien, fee konsultasi tidak akan dibayar penuh". Setiap pelayanan memerlukan bentuk pelayanan yang handal, artinya dalam memberikan pelayanan, setiap pegawai diharapkan memiliki kemampuan dalam pengetahuan, keahlian, kemandirian, penguasaan dan profesionalisme kerja yang tinggi, sehingga aktivitas kerja yang dikerjakan menghasilkan bentuk pelayanan yang memuaskan, tanpa ada keluhan dan kesan yang berlebihan atas pelayanan yang diterima oleh masyarakat.

Parasuraman, (2001:48) menyatakan bahwa "Tuntutan kehandalan pegawai dalam memberikan pelayanan yang cepat, tepat, mudah dan lancar menjadi syarat penilaian bagi orang yang dilayani dalam memperlihatkan aktualisasi kerja pegawai dalam memahami lingkup dan uraian kerja yang menjadi perhatian dan fokus dari setiap pegawai dalam memberikan pelayanannya".

Inti pelayanan kehandalan adalah setiap pegawai memiliki kemampuan yang handal, mengetahui mengenai seluk belum prosedur kerja, mekanisme kerja, memperbaiki berba-gai kekurangan atau penyimpangan yang tidak sesuai dengan prosedur kerja dan mampu menunjukkan, mengarahkan dan memberikan arahan yang benar kepada setiap bentuk pelayanan yang belum dimengerti oleh masyarakat, sehingga memberi dampak positif atas pelayanan tersebut yaitu pegawai memahami, menguasai, handal, mandiri dan profesional atas uraian kerja yang ditekuninya

c. Responsiveness (cepat tanggap) : dimensi kualitas pelayanan tentang kemauan untuk membantu pelanggan (peserta) dan menyediakan jasa/pelayanan yang cepat dan tepat.

Menurut Tjiptono (2012:175) berkenaan dengan kesediaan dan kemampuan penyedia layanan untuk membantu para pelanggan dan merespon permintaan mereka dengan segera.

Parasuraman, (2001:52), mengatakan bahwa setiap pegawai dalam memberikan bentuk-bentuk pelayanan, mengutamakan aspek pelayanan yang sangat mempengaruhi perilaku orang yang mendapat pelayanan, sehingga diperlukan 
kemampuan daya tanggap dari pegawai untuk melayani masyarakat sesuai dengan tingkatpenyerapan, pengertian, ketidaksesuaian atas berbagai hal bentuk pelayanan yang tidak diketahuinya.

Hal ini memerlukan adanya penjelasan yang bijaksana, mendetail, membina, mengarahkan dan membujuk agar menyikapi segala bentuk-bentuk prosedur dan mekanisme kerja yang berlaku dalam suatu organisasi, sehingga bentuk pelayanan mendapat respon positif. Suatu organisasi sangat menyadari pentingnya kualitas layanan daya tanggap atas pelayanan yang diberikan. Setiap orang yang mendapat pelayanan sangat membutuhkan penjelasan atas pelayanan yang diberikan agar pelayanan tersebut jelas dan dimengerti.

Upaya mewujudkan dan merealisasikan hal tersebut, maka kualitas layanan daya tanggap mempunyai peranan penting atas pemenuhan berbagai penjelasan dalam kegiatan pelayanan kepada masyarakat. Apabila pelayanan daya tanggap diberikan dengan baik atas penjelasan yang bijaksana, penjelasan yang mendetail, penjelasan yang membina, penjelasan yang mengarahkan dan yang bersifat membujuk, apabila hal tersebut secara jelas dimengerti oleh individu yang mendapat pelayanan, maka secara langsung pelayanan daya tanggap dianggap berhasil, dan ini menjadi suatu bentuk keberhasilan prestasi kerja.

d. Assurance (kepastian) : dimensi mutu pelayanan yang mencakup pengetahuan dan keramah-tamahan para karyawan dan kemampuan mereka untuk menimbulkan kepercayaan dan keyakinan, kesopanan dan sifat dapat dipercaya yang dimiliki para staf, bebas dari bahaya, risiko atau keragu-raguan.

Menurut Tjiptono (2012: 175) berkenaan dengan pengetahuan dan kesopanan karyawan serta kemampuan mereka dalam menumbuhkan rasa percaya (trust) dan keyakinan pelanggan (confidence). Parasuraman, (2001: 69), mengungkap bahwa setiap bentuk pelayanan memerlukan adanya kepastian atas pelayanan yang diberikan. Bentuk kepastian dari suatu pelayanan sangat ditentukan oleh jaminan dari pegawai yang memberikan pelayanan, sehingga orang yang menerima pelayanan merasa puas dan yakin bahwa segala bentuk urusan pelayanan yang dilakukan atas tuntas dan selesai sesuai 
dengan kecepatan, ketepatan, kemudahan, kelancaran dan kualitas layanan yang diberikan.

Jaminan atas pelayanan yang diberikan oleh pegawai sangat ditentukan oleh performance atau kinerja pelayanan, sehingga diyakini bahwa pegawai tersebut mampu memberikan pelayanan yang handal, mandiri dan profesional yang berdampak pada kepuasan pelayanan yang diterima.Selain dari performance tersebut, jaminan dari suatu pelayanan juga ditentukan dari adanya komitmen organisasi yang kuat, yang menganjurkan agar setiap pegawai memberikan pelayanan secara serius dan sungguh-sungguh untuk memuaskan orang yang dilayani.

Margaretha (2003:201) mengatakan bahwa bentuk jaminan yang lain yaitu jaminan terhadap pegawai yang memiliki perilaku kepribadian (personality behavior) yang baik dalam memberikan pelayanan tentu akan berbeda pegawai yang memiliki watak atau karakter yang kurang baik dan yang kurang baik dalam memberikan pelayanan.

$P$ e $n g$ e $t$ a $h u a n$, kesopansantunan dan kemampuan para pegawai perusahaan untuk menumbuhkan rasa percaya para pelanggan kepada perusahaan. Hal ini meliputi beberapa komponen antara lain komunikasi, kredibilitas, keamanan, kompetensi dan sopan santun

e. Empathy (empati) : dimensi mutu pelayanan yang meliputi pemahaman pemberian perhatian secara individual kepada pelanggan, kemudahan dalam melakukan komunikasi yang baik, dan memahami kebutuhan pelanggan.

Pelayanan akan berjalan dengan lancar dan berkualitas apabila setiap pihak yang berkepentingan dengan pelayanan memiliki adanya rasa empati atau perhatian (empathy) dalam menyelesaikan atau mengurus atau memiliki komitmen yang sama terhadap pelayanan (Parasuraman, 2001: 40).

Empati dalam suatu pelayanan adalah adanya suatu perhatian, keseriusan, simpatik, pengertian dan keterlibatan pihak-pihak yang berkepentingan dengan pelayanan untuk mengembangkan dan melakukan aktivitas pelayanan sesuai dengan tingkat pengertian dan pemahaman dari masing-masing pihak tersebut. Pihak yang memberi pelayanan harus memiliki 
empati memahami masalah dari pihak yang ingin dilayani. Pihak yang dilayani seyogyanya memahami keterbatasan dan kemampuan orang yang melayani, sehingga keterpaduan antara pihak yang melayani dan mendapat pelayanan memiliki perasaan yang sama.

Pada penelitian ini (Analisis Tingkat Harapan dan Kepuasan peserta terhadap Penyelenggaraan diklat Fungsional Guru Madya IPS Pusdiklat Tenaga Teknis Pendidikan dan Keagamaan), menggunakan pengukuran lima dimensi kualitas pelayanan tersebut, yaitu: (1) Keandalan (reliability); (2) Empati (emphaty)' (3) Berwujud (tangible); (3)Keresponsifan (responsiveness); dan Jaminan (assurance).

5. Teori Kinerja (Job Performance)

Ada beberapa defenisi atau batasan mengenai kinerja atau job performance, sebagaimana dikutip oleh As'ad (1998) bahwa Job performance is successful role achievement (kinerja itu diperoleh seseorang dari perbuatannya)". Sedangkan Suyadi Prawirosentorso (1992:2) menyatakan bahwa "Kinerja adalah hasil kerja yang dapat dicapai seseorang atau kelompok orang dalam suatu organisasi, sesuai dengan wewenang, dan tanggung jawab masing-masing dalam rangka mencapai tujuan organisasi bersangkutan secara legal, tidak melanggar hukum dan sesuai dengan moral maupun etika".

Berdasar batasan tersebut, jelaslah bahwa yang dimaksud dengan job performance ialah hasil yang dicapai seseorang menurut ukuran yang berlaku, dan untuk pekerjaan yang bersangkutan. Tingkat keberhasilan seorang di dalam melaksanakan tugas dan pekerjaannya dinamakan level of performance. Orang yang level of performance-nya tinggi dikatakan orang yang produktif, sedang orang yang level performance-nya tidak mencapai standar disebut tidak produktif atau performancenya rendah.

Moenir (1996:68) mengatakan bahwa "Kinerja seseorang berbedabeda karena situasi yang berbeda dan kerja seseorang dengan orang lain juga bisa berbeda, hal ini disebabkan oleh perbedaan karakteristik dari masing-masing individu". Kinerja berdasarkan tinjau di atas, adalah secara kualitas dan kuantitas yang dicapai oleh seseorang pegawai dalam melaksanakan tugasnya sesuai dengan tanggung jawab yang diberikan kepadanya.

Langkah untuk mengetahui kinerja pegawai, maka perlu diadakan evaluasi terhadap hasil kerja setiap pegawai. Hasil dari evaluasi kinerja dimaksudkan untuk 
memperbaiki atau meningkatkan kinerja pegawai dimasa yang akan datang.

Stephen P. Robbins (2002:258) menyatakan bahwa "Tujuan penilaian kinerja adalah: (a) mengambil keputusan personalia secara umum; (b) pemberian penjelasan tentang pelatihan dan pengembagan yang dibutuhkan; (c) sebagai kriteria untuk program seleksi dan pengembangan; (d) memenuhi tujuan umpan balik yang ada terhadap para pekerja tentang bagaimana organisasi memandang kinerja mereka; dan (e) sebagai dasar untuk mengalokasikan atau menentukan pengahrgaan. Kelima hal tersebut dapat digunakan untuk mengukur standar kinerja yang diperlukan.

Sedangkan

Salamoen dan Nasri Effendi (2001:22) mengemukakan bahwa "Pengukuran kinerja merupakan suatu alat manajemen untuk meningkatkan kualitas pengambilan keputusan dan akuntabilitas". Keberhasilan suatu organisasi sangat dipengaruh oleh kerja individu dan kelompok, dan berhubungan erat dengan memberdayakan dan mengelola seefektif mungkin segala sumber daya manusia.

Davis (1964:484) mengatakan bahwa "Dalam pencapaian kinerja juga dipengaruhi oleh beberapa faktor yaitu faktor kemampuan (ability) dan faktor motivasi (motivation)". Secara psikologis, kemampuan (ability) pegawai terdiri dari kemampuan potensi (IQ) dan kemampuan realitas (knowledge + skill). Artinya pegawai yang memiliki IQ di atas rata-rata (IQ = 100-120) dengan pendidikan yang memadai untuk jabatannya dan terampil dalam mengerjakan pekerjaan sehari-hari, maka ia akan lebih mudah mencapai pekerjaan yang sesuai dengan keahliannya (the right man in right place, the man on the right job)

Motivasi terbentuk dari sikap (attitude) seorang pegawai dalam menghadapi situasi kerja. Motivasi merupakan kondisi yang menggerakkan diri pegawai yang terarah untuk mencapai tujuan organisasi. Sikap mental merupakan kondisi mental yang mendorong pegawai untuk berusaha mencapai prestasi kerja maksimal.

\section{METODE}

\section{Metode penelitian}

Penelitian menggunakan metode kuantitatif dengan model Importance Performance Analysis (John A. Martila and John C. James dalam J. Suptranto, 2003:403). Model ini merupakan bentuk pengukuran kepuasan yang dilakukan dengan cara meminta responden untuk merangking berbagai elemen dari pelayanan yang ditawarkan, serta mengukur kinerja pelayanan masing-masing elemen tersebut, 


\section{Subjek penelitian}

Subjek penelitian ini adalah peserta diklat teknis Fungsional Guru Tingkat Madya IPS MTs Pusdiklat Tenaga Teknis Pendidikan dan Keagamaan, yang berjumlah 60 orang. Penelitian ini dilaksanakan di Pusdiklat Tenaga Teknis Pendidikan dan Keagamaan dari bulan Mei sampai dengan September 2018.

\section{Teknik pengumpulan data dan pengembangan instrumen}

Data diambil dari data primer dan data sekunder. Data primer adalah hasil angket dengan menggunakan instrumen kualitas pelayanan berupa angket dan pedoman wawancara. Pedoman wawancara dipergunakan untuk memperoleh informasi mengenai penyelenggaraan diklat yang meliputi: Responsiveness, Empathy, Tangibel, Reliability, Assurance. Sedangkan data sekunder adalah data yang diambil melalui riset kepustakaan yang relevan.

\section{Instrumen Pengumpulan Data}

Instrumen pengumpulan data yang digunakan adalah kuesioner/ angket. Angket yang digunakan berisi butir-butir pertanyaan mengenai tingkat harapan dan kepuasan peserta. Asumsi yang mendasari digunakan metode angket adalah subyek merupakan orang yang paling tahu tentang tingkat harapan dan kepuasan saat menjadi peserta diklat Pusdiklat Tenaga Teknis, apa yang ditanyakan oleh peneliti kepada subjek adalah benar dan dapat dipercaya.

\section{Teknik analisis data}

Langkah menganalisis data penelitian ini digunakan metode deskriptif kuantitatif. Untuk menjawab perumusan masalah mengenai apakah harapan peserta terpenuhi, digunakan model Importance-Performance Analysis atau Analisis Tingkat Harapan Kepuasan Pelanggan. Kelima dimensi kualitas pelayanan tersebut, dengan menggunakan skala 5 tingkat (skala likert). Berdasarkan hasil penilaian tingkat Harapan dan hasil kepuasan maka dihasilkan suatu perhitungan mengenai tingkat kesesuaian antara tingkat harapan dan kepuasan.

Dengan Diagram Kartesius yang merupakan suatu bangun dibagi empat bagian yang dibatasi oleh dua buah garis yang berpotongan tegak lurus pada titik titik $(X, Y)$ dimana $X$ merupakan rata-rata dari rata-rata skor tingkat kepuasan seluruh faktor dan $Y$ adalah ratarata dari rata-rata skor tingkat harapan seluruh faktor yang mempengaruhi kepuasan peserta, selanjutnya tingkat unsur-unsur tersebut dijabarkan dan dibagi menjadi empat bagian kedalam diagram Kartesius. Seperti pada gambar dibawah ini : 


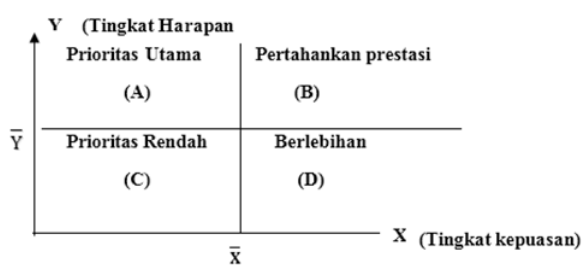

Keterangan :

1. Kuadran A menunjukkan faktor-faktor yang dianggap sangat penting, namun pihak penyelenggara diklat belum melaksanakannya sesuai keinginan/harapan peserta

2. Kuadran B menunjukkan faktor-faktor yang dianggap sangat penting telah berhasil dilaksanakan sesuai harapan peserta dansangatmemuaskan (sangat baik) sehingga wajib dipertahankan.

3. Kuadran C menunjukkan faktor-faktor yang dianggap kurang penting oleh peserta, pelaksanaannya dijalankan secara cukup atau biasabiasa saja.

4. Kuadran D menunjukkan faktor-faktor yang kurang penting, tetapi dilaksanakan sangat baik (pelaksanaannya berlebihan).

Untuk selanjutnya dapat dicari skor rata-rata tingkat pelaksanaan dan skor rata-rata tingkat harapan dari setiap determinan/dimensi faktor yang mempengaruhi kepuasan peserta, dengan rumus (J.Supranto,203:403), sebagai berikut:

$$
\begin{array}{l|l}
\overline{\mathrm{X}}=\frac{\Sigma \mathrm{Xi}_{\mathrm{i}}}{\mathrm{n}} & \overline{\mathrm{Y}}=\frac{\Sigma \mathrm{Yi}}{\mathrm{n}}
\end{array}
$$

Dimana :

$\overline{\mathrm{X}}=$ Skor rata-rata tingkat kepuasan

$\overline{\mathrm{Y}}=$ Skor rata-rata tingkat harapan

$\mathrm{n}$ = Jumlah responden sebagai sampel

Berdasarkan hasil penilaian tingkat harapan dan hasil kepuasan, maka dihasilkan suatu perhitungan mengenai tingkat kesesuaian antara tingkat harapan dan kepuasan.

Tingkat kesesuaian adalah hasil perbandingan skor kepuasan dengan skor harapan. Untuk menentukan hal tersebut, maka rumus yang digunakan adalah (J.Supranto, 2003:403):

$$
\mathrm{T} k \mathrm{i}=\frac{\mathrm{xi}}{\mathrm{Yi}} \times 100 \%
$$

Dimana :

Tki = Tingkat kesesuaian peserta

$\mathrm{Xi}=$ Skor penilaian kepuasan peserta

$\mathrm{Yi}=$ Skor penilaian harapan peserta

Dengan Diagram Kartesius yang merupakan suatu bangun dibagi empat bagian yang dibatasi oleh dua buah garis yang berpotongan tegak lurus pada titiktitik ( $X, Y$ ) dimana $X$ merupakan rata-rata dari rata-rata skor tingkat 
kepuasan seluruh faktor, dan $Y$ adalah rata-rata dari rata-rata skor tingkat harapan seluruh faktor yang mempengaruhi kepuasan peserta. Untuk menentukan nilai rata-rata tersebut, maka rumus yang dipergunakan adalah sebagai berikut:

$$
\overline{\mathrm{X}}_{1}=\frac{\sum \overline{\mathrm{X}}_{\mathrm{ij}}}{\mathrm{n}} \quad \overline{\mathrm{Y}}_{1}=\frac{\sum \overline{\mathrm{Y}}_{\mathrm{ij}}}{\mathrm{n}}
$$

Keterangan :

$\overline{\mathrm{X}_{1}}=$ skor rata-rata seluruh faktor kepuasan atribut ke- $\mathrm{i}$ $=1-32$ (jumlah atribut)

$\bar{Y}_{1}=$ skor rata-rata faktor harapan atribut ke-i=1-32 (jumlah atribut)

$X_{i j}=$ skor penilaian kepuasan atribut ke-i dari responden ke j

$Y_{i j}=$ skor penilaian harapan atribut ke-i dari responden ke j

$\mathrm{j}=$ responden $\mathrm{ke} \mathrm{j}$

$\mathrm{n}$ = Banyaknya faktor yang dapat mempengaruhi kepuasan pelanggan.

\section{HASIL DAN PEMBAHASAN}

\section{Hasil penelitian}

Hasil penelitian 60 responden diuraikan seperti disajikan dibawah ini sebagai berikut:

\section{a. Analisis Keresposifan (responsiveness)}

Kesigapan adalah kemauan untuk membantu peserta dan memberikan pelayanan dengan cepat. Aspek ini meliputi:

1) Kemudahan menghubungi Pusdiklat tentang informasi.

Dari 60 responden yang dianalisis telah diperoleh penilaian terhadap tingkat harapan mengenai kemudahan menghubungi Pusdiklat tentang informasi, sebagaimana tertera pada tabel 1.1 sedangkan penilaian peserta mengenai kemudahan menghubungi Pusdiklat tentang informasi disajikan pada tabel 1.2

Tabel 1.1.

Tingkat harapan peserta mengenai kemudahan menghubungi Pusdiklat tentang informasi

\begin{tabular}{|c|c|c|c|c|c|}
\hline $\begin{array}{c}\text { Sangat } \\
\text { Berharap }\end{array}$ & $\begin{array}{c}\text { Ber- } \\
\text { harap }\end{array}$ & $\begin{array}{c}\text { Cukup } \\
\text { Berharap }\end{array}$ & $\begin{array}{c}\text { Kurang } \\
\text { berharap }\end{array}$ & $\begin{array}{c}\text { Tidak } \\
\text { berharap }\end{array}$ & $\begin{array}{c}\text { Bobot } \\
\text { nilai }\end{array}$ \\
\hline 33 & 20 & 7 & 0 & 0 & 166 \\
\hline
\end{tabular}

Sumber: Hasil kuesioner

Keterangan angka:

$$
166=(33 \times 5)+(20 \times 4)+(7 \times 3)
$$

Tabel 1.2.

Penilaian peserta terhadap kinerja kemudahan menghubungi Pusdiklat tentang informasi

\begin{tabular}{|c|c|c|c|c|c|}
\hline $\begin{array}{c}\text { Sangat } \\
\text { puas }\end{array}$ & Puas & $\begin{array}{c}\text { Cukup } \\
\text { puas }\end{array}$ & $\begin{array}{c}\text { Kurang } \\
\text { puas B }\end{array}$ & $\begin{array}{c}\text { Tidak } \\
\text { puas }\end{array}$ & $\begin{array}{c}\text { Bobot } \\
\text { nilai }\end{array}$ \\
\hline 11 & 44 & 5 & 0 & 0 & 246 \\
\hline
\end{tabular}

Sumber: Hasil kuesioner

Keterangan angka:

$$
246=(11 \times 5)+(44 \times 4)+(5 \times 3)
$$

2) Keramahan, perhatian dan kesopanan panitia, widyaiswara, berserta petugas

Dari 60 responden yang dianalisis telah diperoleh 
penilaian terhadap tingkat harapan mengenai keramahan, perhatian dan kesopanan panitia, widyaiswara, berserta petugas, sebagaimana tertera pada tabel 2.1 sedangkan penilaian peserta terhadap keramahan, perhatian dan kesopanan panitia, widyaiswara, berserta petugas disajikan pada tabel 2.2.

Tabel 2.1.

Tingkat harapan peserta mengenai keramahan, perhatian dan kesopanan panitia, widyaiswara, berserta petugas

\begin{tabular}{|c|c|c|c|c|c|}
\hline $\begin{array}{c}\text { Sangat } \\
\text { Berharap }\end{array}$ & $\begin{array}{c}\text { Ber- } \\
\text { harap }\end{array}$ & $\begin{array}{c}\text { Cukup } \\
\text { Berharap }\end{array}$ & $\begin{array}{c}\text { Kurang } \\
\text { berharap }\end{array}$ & $\begin{array}{c}\text { Tidak } \\
\text { berharap }\end{array}$ & $\begin{array}{c}\text { Bobot } \\
\text { nilai }\end{array}$ \\
\hline 34 & 21 & 5 & 0 & 0 & 269 \\
\hline
\end{tabular}

Sumber: Hasil kuesioner

Keterangan angka:

$$
269=(34 \times 5)+(21 \times 4)+(5 \times 3)
$$

Tabel 2.2.

Penilaian peserta terhadap kinerja keramahan, perhatian dan kesopanan panitia, widyaiswara, berserta petugas

\begin{tabular}{|c|c|c|c|c|c|}
\hline $\begin{array}{c}\text { Sangat } \\
\text { Berharap }\end{array}$ & $\begin{array}{c}\text { Ber- } \\
\text { harap }\end{array}$ & $\begin{array}{c}\text { Cukup } \\
\text { Berharap }\end{array}$ & $\begin{array}{c}\text { Kurang } \\
\text { berharap }\end{array}$ & $\begin{array}{c}\text { Tidak } \\
\text { berharap }\end{array}$ & $\begin{array}{c}\text { Bobot } \\
\text { nilai }\end{array}$ \\
\hline 34 & 21 & 5 & 0 & 0 & 269 \\
\hline
\end{tabular}

Sumber: Hasil kuesioner

Keterangan angka:

$$
169=(31 \times 5)+(27 \times 4)+(2 \times 3)
$$

3) Kecepatan panitia / petugas / widyaiswara / narasumber dalam menangani keluhan.

Dari 60 responden yang dianalisis telah diperoleh penilaian terhadap tingkat harapan mengenai kecepatan panitia, petugas, widyaiswara/narasumber dalam me-nangani keluhan, sebagaimana tertera pada tabel 3.1 sedangkan penilaian peserta terhadap kinerja kecepatan panitia, petugas, widyaiswara/narasumber dalam menangani keluhan. Disajikan pada tabel 3.2.

Tabel 3.1.

Tingkat harapan peserta mengenai kecepatan panitia/petugas/widyaiswara/ narasumber dalam menangani keluhan

\begin{tabular}{|c|c|c|c|c|c|}
\hline $\begin{array}{c}\text { Sangat } \\
\text { Berharap }\end{array}$ & $\begin{array}{c}\text { Ber- } \\
\text { harap }\end{array}$ & $\begin{array}{c}\text { Cukup } \\
\text { Berharap }\end{array}$ & $\begin{array}{c}\text { Kurang } \\
\text { berharap }\end{array}$ & $\begin{array}{c}\text { Tidak } \\
\text { berharap }\end{array}$ & $\begin{array}{c}\text { Bobot } \\
\text { nilai }\end{array}$ \\
\hline 31 & 22 & 7 & 0 & 0 & 294 \\
\hline
\end{tabular}

Sumber: Hasil kuesioner

Keterangan angka:

$$
294=(31 \times 5)+(22 \times 4)+(7 \times 3)
$$

Tabel 3.2.

Penilaian peserta terhadap kinerja kecepatan panitia/petugas/widyaiswara/ narasumber dalam menangani keluhan

\begin{tabular}{|c|c|c|c|c|c|}
\hline $\begin{array}{c}\text { Sangat } \\
\text { puas }\end{array}$ & Puas & $\begin{array}{c}\text { Cukup } \\
\text { puas }\end{array}$ & $\begin{array}{c}\text { Kurang } \\
\text { puas B }\end{array}$ & $\begin{array}{c}\text { Tidak } \\
\text { puas }\end{array}$ & $\begin{array}{c}\text { Bobot } \\
\text { nilai }\end{array}$ \\
\hline 15 & 29 & 7 & 6 & 2 & 246 \\
\hline
\end{tabular}

Sumber: Hasil kuesioner

Keterangan angka:

$$
\begin{aligned}
156=(15 \times 5)+ & (29 \times 4)+(7 \times 3)+(6 \times 2) \\
& +(2 \times 1)
\end{aligned}
$$

4) Narasumber/widyaiswara disiplin dan bertanggung jawab terhadap pelatihan.

Dari 60 responden yang dianalisis telah diperoleh penilaian terhadap tingkat harapan mengenai Narasumber/widyaiswara disiplin dan bertanggung jawab terhadap 
pelatihan., sebagaimana tertera pada tabel 4.1 sedangkan penilaian peserta mengenai kinerja narasumber/widyaiswara disiplin dan bertanggung jawab terhadap pelatihan disajikan pada tabel 4.2.

Tabel 4.1.

Tingkat harapan peserta mengenai Narasumber/widyaiswara disiplin dan bertanggung jawab terhadap pelatihan.

\begin{tabular}{|c|c|c|c|c|c|}
\hline $\begin{array}{c}\text { Sangat } \\
\text { Berharap }\end{array}$ & $\begin{array}{c}\text { Ber- } \\
\text { harap }\end{array}$ & $\begin{array}{c}\text { Cukup } \\
\text { Berharap }\end{array}$ & $\begin{array}{c}\text { Kurang } \\
\text { berharap }\end{array}$ & $\begin{array}{c}\text { Tidak } \\
\text { berharap }\end{array}$ & $\begin{array}{c}\text { Bobot } \\
\text { nilai }\end{array}$ \\
\hline 36 & 21 & 3 & 0 & 0 & 270 \\
\hline
\end{tabular}

Sumber: Hasil kuesioner

Keterangan angka:

$$
270=(36 \times 5)+(21 \times 4)+(3 \times 3)
$$

Tabel 4.2.

Penilaian peserta terhadap kinerja Narasumber/widyaiswara disiplin dan bertanggung jawab terhadap pelatihan.

\begin{tabular}{|c|c|c|c|c|c|}
\hline $\begin{array}{c}\text { Sangat } \\
\text { puas }\end{array}$ & Puas & $\begin{array}{c}\text { Cukup } \\
\text { puas }\end{array}$ & $\begin{array}{c}\text { Kurang } \\
\text { puas }\end{array}$ & $\begin{array}{c}\text { Tidak } \\
\text { puas }\end{array}$ & $\begin{array}{c}\text { Bobot } \\
\text { nilai }\end{array}$ \\
\hline 37 & 20 & 3 & 0 & 0 & 174 \\
\hline
\end{tabular}

Sumber: Hasil kuesioner

Keterangan angka:

$$
174=(37 \times 5)+(20 \times 4)+(3 \times 3)
$$

5) Informasi adanya diklat diberiakan 1 (satu) minggu sebelum pelaksanaan diklat.

Dari 60 responden yang dianalisis telah diperoleh penilaian terhadap tingkat harapan mengenai informasi adanya diklat diberiakan 1 (satu) minggu sebelum pelaksanaan diklat, sebagaimana tertera pada tabel 5.1 sedangkan penilaian peserta mengenai kinerja informasi adanya diklat diberiakan 1 (satu) minggu sebelum pelaksanaan diklat disajikan pada tabel 5.2

Tabel 5.1.

Tingkat harapan peserta mengenai kemudahan menghubungi Pusdiklat tentang informasi

\begin{tabular}{|c|c|c|c|c|c|}
\hline $\begin{array}{c}\text { Sangat } \\
\text { Berharap }\end{array}$ & $\begin{array}{c}\text { Ber- } \\
\text { harap }\end{array}$ & $\begin{array}{c}\text { Cukup } \\
\text { Berharap }\end{array}$ & $\begin{array}{c}\text { Kurang } \\
\text { berharap }\end{array}$ & $\begin{array}{c}\text { Tidak } \\
\text { berharap }\end{array}$ & $\begin{array}{c}\text { Bobot } \\
\text { nilai }\end{array}$ \\
\hline 30 & 25 & 5 & 0 & 0 & 265 \\
\hline
\end{tabular}

Sumber: Hasil kuesioner

Keterangan angka:

$$
265=(30 \times 5)+(25 \times 4)+(5 \times 3)
$$

Tabel 5.2.

Penilaian peserta terhadap kinerja kemudahan menghubungi Pusdiklat tentang informasi

\begin{tabular}{|c|c|c|c|c|c|}
\hline $\begin{array}{c}\text { Sangat } \\
\text { puas }\end{array}$ & Puas & $\begin{array}{c}\text { Cukup } \\
\text { puas }\end{array}$ & $\begin{array}{c}\text { Kurang } \\
\text { puas B }\end{array}$ & $\begin{array}{c}\text { Tidak } \\
\text { puas }\end{array}$ & $\begin{array}{c}\text { Bobot } \\
\text { nilai }\end{array}$ \\
\hline 24 & 20 & 12 & 4 & 0 & 244 \\
\hline
\end{tabular}

Sumber: Hasil kuesioner

Keterangan angka:

$244=(24 \times 5)+(20 \times 4)+(12 \times 3)+(4 \times 2)$

\section{b. Analisis Empati (empathy)}

Empati adalah kesediaan untuk peduli, memberi perhatian pribadi bagi peserta. Aspek ini meliputi;

1) Kemampuan

panitia, narasumber/widyaiswara dan petugas berkomunikasi dengan peserta.

Dari 60 responden yang dianalisis telah diperoleh penilaian terhadap tingkat harapan mengenai kemampuan panitia, narasumber/ widyaiswara dan petugas 
berkomunikasi dengan peserta, sebagaimana tertera pada tabel 6.1 sedangkan penilaian peserta mengenai kinerja kemampuan panitia, narasumber/widyaiswara dan petugas berkomunikasi dengan peserta disajikan pada tabel 6.2.

\section{Tabel 6.1.}

Tingkat harapan peserta mengenai kemudahan menghubungi Pusdiklat tentang informasi

\begin{tabular}{|c|c|c|c|c|c|}
\hline $\begin{array}{c}\text { Sangat } \\
\text { Berharap }\end{array}$ & $\begin{array}{c}\text { Ber- } \\
\text { harap }\end{array}$ & $\begin{array}{c}\text { Cukup } \\
\text { Berharap }\end{array}$ & $\begin{array}{c}\text { Kurang } \\
\text { berharap }\end{array}$ & $\begin{array}{c}\text { Tidak } \\
\text { berharap }\end{array}$ & $\begin{array}{c}\text { Bobot } \\
\text { nilai }\end{array}$ \\
\hline 30 & 25 & 5 & 0 & 0 & 265 \\
\hline
\end{tabular}

Sumber: Hasil kuesioner

Keterangan angka:

$$
265=(30 \times 5)+(25 \times 4)+(5 \times 3)
$$

Tabel 6.2.

Penilaian peserta terhadap kinerja kemudahan menghubungi Pusdiklat tentang informasi

\begin{tabular}{|c|c|c|c|c|c|}
\hline $\begin{array}{c}\text { Sangat } \\
\text { puas }\end{array}$ & Puas & $\begin{array}{c}\text { Cukup } \\
\text { puas }\end{array}$ & $\begin{array}{c}\text { Kurang } \\
\text { puas }\end{array}$ & $\begin{array}{c}\text { Tidak } \\
\text { puas }\end{array}$ & $\begin{array}{c}\text { Bobot } \\
\text { nilai }\end{array}$ \\
\hline 23 & 31 & 6 & 0 & 0 & 257 \\
\hline
\end{tabular}

Sumber: Hasil kuesioner

Keterangan angka:

$$
257=(23 \times 5)+(31 \times 4)+(6 \times 3)
$$

2) Informasi yang jelas mengenai jadwal pelaksanaan diklat.

Dari 60 responden yang dianalisis telah diperoleh penilaian terhadap tingkat harapan mengenai Informasi yang jelas mengenai jadwal pelaksanaan diklat, sebagaimana tertera pada tabel 7.1 sedangkan penilaian peserta mengenai kinerja Informasi yang jelas mengenai jadwal pelaksanaan diklat disajikan pada tabel 7.2.

Tabel 7.1.

Tingkat harapan peserta mengenai Informasi yang jelas mengenai jadwal pelaksanaan diklat

\begin{tabular}{|c|c|c|c|c|c|}
\hline $\begin{array}{c}\text { Sangat } \\
\text { Berharap }\end{array}$ & $\begin{array}{c}\text { Ber- } \\
\text { harap }\end{array}$ & $\begin{array}{c}\text { Cukup } \\
\text { Berharap }\end{array}$ & $\begin{array}{c}\text { Kurang } \\
\text { berharap }\end{array}$ & $\begin{array}{c}\text { Tidak } \\
\text { berharap }\end{array}$ & $\begin{array}{c}\text { Bobot } \\
\text { nilai }\end{array}$ \\
\hline 34 & 18 & 8 & 0 & 0 & 266 \\
\hline
\end{tabular}

Sumber: Hasil kuesioner

Keterangan angka:

$$
266=(34 \times 5)+(18 \times 4)+(8 \times 3)
$$

Tabel 7.2

Penilaian peserta terhadap kinerja Informasi yang jelas mengenai jadwal pelaksanaan diklat

\begin{tabular}{|c|c|c|c|c|c|}
\hline $\begin{array}{c}\text { Sangat } \\
\text { puas }\end{array}$ & Puas & $\begin{array}{c}\text { Cukup } \\
\text { puas }\end{array}$ & $\begin{array}{c}\text { Kurang } \\
\text { puas B }\end{array}$ & $\begin{array}{c}\text { Tidak } \\
\text { puas }\end{array}$ & $\begin{array}{c}\text { Bobot } \\
\text { nilai }\end{array}$ \\
\hline 22 & 29 & 9 & 1 & 0 & 255 \\
\hline
\end{tabular}

Sumber: Hasil kuesioner

Keterangan angka:

$$
255=(22 \times 5)+(29 \times 4)+(9 \times 3)+(1 \times 2)
$$

3) Informasi yang jelas mengenai peraturan dalam diklat

Dari 60 responden yang dianalisis telah diperoleh penilaian terhadap tingkat harapan mengenai Informasi yang jelas mengenai peraturan dalam diklat, sebagaimana tertera pada tabel 8.1 sedangkan penilaian peserta mengenai kinerja Informasi yang jelas mengenai peraturan dalam diklatdisajikan pada tabel 8.2. 
Tabel 8.1.

Tingkat harapan peserta mengenai kemudahan menghubungi Pusdiklat tentang informasi

\begin{tabular}{|c|c|c|c|c|c|}
\hline $\begin{array}{c}\text { Sangat } \\
\text { Berharap }\end{array}$ & $\begin{array}{c}\text { Ber- } \\
\text { harap }\end{array}$ & $\begin{array}{c}\text { Cukup } \\
\text { Berharap }\end{array}$ & $\begin{array}{c}\text { Kurang } \\
\text { berharap }\end{array}$ & $\begin{array}{c}\text { Tidak } \\
\text { berharap }\end{array}$ & $\begin{array}{c}\text { Bobot } \\
\text { nilai }\end{array}$ \\
\hline 28 & 29 & 3 & 0 & 0 & 265 \\
\hline
\end{tabular}

Sumber: Hasil kuesioner

Keterangan angka:

$$
265=(28 \times 5)+(29 \times 4)+(3 \times 3)
$$

Tabel 8.2.

Penilaian peserta terhadap kinerja kemudahan menghubungi Pusdiklat tentang informasi

\begin{tabular}{|c|c|c|c|c|c|}
\hline $\begin{array}{c}\text { Sangat } \\
\text { puas }\end{array}$ & Puas & $\begin{array}{c}\text { Cukup } \\
\text { puas }\end{array}$ & $\begin{array}{c}\text { Kurang } \\
\text { puas B }\end{array}$ & $\begin{array}{c}\text { Tidak } \\
\text { puas }\end{array}$ & $\begin{array}{c}\text { Bobot } \\
\text { nilai }\end{array}$ \\
\hline 18 & 31 & 11 & 0 & 0 & 247 \\
\hline
\end{tabular}

Sumber : Hasil kuesioner

Keterangan angka :

$$
247=18 \times 5+31 \times 4+11 \times 3
$$

4) Informasi yang jelas menganai fasilitas peserta.

Dari 60 responden yang dianalisis telah diperoleh penilaian terhadap tingkat harapan mengenai Informasi yang jelas menganai fasilitas peserta, sebagaimana tertera pada tabel 9.1 sedangkan penilaian peserta mengenai kinerja Informasi yang jelas menganai fasilitas peserta disajikan pada tabel 9.2.
Tabel 9.1.

Tingkat harapan peserta mengenai kemudahan menghubungi Pusdiklat tentang informasi

\begin{tabular}{|c|c|c|c|c|c|}
\hline $\begin{array}{c}\text { Sangat } \\
\text { Berharap }\end{array}$ & $\begin{array}{c}\text { Ber- } \\
\text { harap }\end{array}$ & $\begin{array}{c}\text { Cukup } \\
\text { Berharap }\end{array}$ & $\begin{array}{c}\text { Kurang } \\
\text { berharap }\end{array}$ & $\begin{array}{c}\text { Tidak } \\
\text { berharap }\end{array}$ & $\begin{array}{c}\text { Bobot } \\
\text { nilai }\end{array}$ \\
\hline 28 & 28 & 4 & 0 & 0 & 263 \\
\hline
\end{tabular}

Sumber: Hasil kuesioner

Keterangan angka:

$$
263=(28 \times 5)+(28 \times 4)+(4 \times 3)
$$

Tabel 9.2.

Penilaian peserta terhadap kinerja kemudahan menghubungi Pusdiklat tentang informasi

\begin{tabular}{|c|c|c|c|c|c|}
\hline $\begin{array}{c}\text { Sangat } \\
\text { puas }\end{array}$ & Puas & $\begin{array}{c}\text { Cukup } \\
\text { puas }\end{array}$ & $\begin{array}{c}\text { Kurang } \\
\text { puas. B }\end{array}$ & $\begin{array}{c}\text { Tidak } \\
\text { puas }\end{array}$ & $\begin{array}{c}\text { Bobot } \\
\text { nilai }\end{array}$ \\
\hline 21 & 32 & 6 & 1 & 0 & 245 \\
\hline
\end{tabular}

Sumber: Hasil kuesioner

Keterangan angka:

$245=(21 \times 5)+(32 \times 4)+(6 \times 3)+(1 \times 2)$

5) Informasi program yang diberikan membantu dalam kesiapan mengikuti diklat.

Dari 60 responden yang dianalisis telah diperoleh penilaian terhadap tingkat harapan mengenai Informasi program yang diberikan membantu dalam kesiapan mengikuti diklat, sebagaimana tertera pada tabel 10.1 sedangkan penilaian peserta mengenai kinerja Informasi program yang diberikan membantu dalam kesiapan mengikuti diklat disajikan pada tabel 10.2. 
Tabel 10.1.

Tingkat harapan peserta mengenai Informasi program yang diberikan membantu dalam kesiapan mengikuti diklat

\begin{tabular}{|c|c|c|c|c|c|}
\hline $\begin{array}{c}\text { Sangat } \\
\text { Berharap }\end{array}$ & $\begin{array}{c}\text { Ber- } \\
\text { harap }\end{array}$ & $\begin{array}{c}\text { Cukup } \\
\text { Berharap }\end{array}$ & $\begin{array}{c}\text { Kurang } \\
\text { berharap }\end{array}$ & $\begin{array}{c}\text { Tidak } \\
\text { berharap }\end{array}$ & $\begin{array}{c}\text { Bobot } \\
\text { nilai }\end{array}$ \\
\hline 27 & 28 & 4 & 1 & 0 & 261 \\
\hline
\end{tabular}

Sumber: Hasil kuesioner

Keterangan angka:

$261=(27 \times 5)+(28 \times 4)+(4 \times 3)+(1 \times 2)$

Tabel 10.2.

Penilaian peserta terhadap kinerja Informasi program yang diberikan membantu dalam kesiapan mengikuti diklat

\begin{tabular}{|c|c|c|c|c|c|}
\hline $\begin{array}{c}\text { Sangat } \\
\text { puas }\end{array}$ & Puas & $\begin{array}{c}\text { Cukup } \\
\text { puas }\end{array}$ & $\begin{array}{c}\text { Kurang } \\
\text { puas. B }\end{array}$ & $\begin{array}{c}\text { Tidak } \\
\text { puas }\end{array}$ & $\begin{array}{c}\text { Bobot } \\
\text { nilai }\end{array}$ \\
\hline 16 & 32 & 12 & 0 & 0 & 244 \\
\hline
\end{tabular}

Sumber: Hasil kuesioner

Keterangan angka:

$244=(16 \times 5)+(32 \times 4)+(12 \times 3)$

6) Widyaiswara memberikan motivasi kepada peserta diklat

Dari 60 responden yang dianalisis telah diperoleh penilaian terhadap tingkat harapan mengenai Widyaiswara memberikan motivasi kepada peserta diklat, sebagaimana tertera pada tabel 11.1 sedangkan penilaian peserta mengenai kinerja Widyaiswara memberikan motivasi kepada peserta diklat disajikan pada tabel 11.2.
Tabel 11.1.

Tingkat harapan peserta mengenai Widyaiswara memberikan motivasi kepada peserta diklat

\begin{tabular}{|c|c|c|c|c|c|}
\hline $\begin{array}{c}\text { Sangat } \\
\text { Berharap }\end{array}$ & $\begin{array}{c}\text { Ber- } \\
\text { harap }\end{array}$ & $\begin{array}{c}\text { Cukup } \\
\text { Berharap }\end{array}$ & $\begin{array}{c}\text { Kurang } \\
\text { berharap }\end{array}$ & $\begin{array}{c}\text { Tidak } \\
\text { berharap }\end{array}$ & $\begin{array}{c}\text { Bobot } \\
\text { nilai }\end{array}$ \\
\hline 38 & 18 & 4 & 0 & 0 & 274 \\
\hline
\end{tabular}

Sumber: Hasil kuesioner

Keterangan angka:

$$
274=(38 \times 5)+(18 \times 4)+(4 \times 3)
$$

Tabel 11.2.

Penilaian peserta terhadap kinerja Widyaiswara memberikan motivasi kepada peserta diklat

\begin{tabular}{|c|c|c|c|c|c|}
\hline $\begin{array}{c}\text { Sangat } \\
\text { puas }\end{array}$ & Puas & $\begin{array}{c}\text { Cukup } \\
\text { puas }\end{array}$ & $\begin{array}{c}\text { Kurang } \\
\text { puas. B }\end{array}$ & $\begin{array}{c}\text { Tidak } \\
\text { puas }\end{array}$ & $\begin{array}{c}\text { Bobot } \\
\text { nilai }\end{array}$ \\
\hline 27 & 26 & 5 & 2 & 0 & 258 \\
\hline
\end{tabular}

Sumber: Hasil kuesioner

Keterangan angka:

$$
258=(27 \times 5)+(26 \times 4)+(5 \times 3)+(2 \times 2)
$$

\section{c. Analisis Bukti Fisik/Berwujud (tangible)}

Bukti fisik adalah penampilan fasilitas fisik, peralatan, perlengkapan, personil, materi, dan komuikasi yang dapat dilihat baik maupun media yang digunakan. Aspek ini meliputi;

1) Penampilan gedung yang baik

Dari 60 responden yang dianalisis telah diperoleh penilaian terhadap tingkat harapan mengenai penampilan gedung yang baik, sebagaimana tertera pada tabel 12.1 sedangkan penilaian peserta mengenai kinerja penampilan gedung yang baik disajikan pada tabel 12.2 . 
Tabel 12.1.

Tingkat harapan peserta mengenai penampilan gedung yang baik

\begin{tabular}{|c|c|c|c|c|c|}
\hline $\begin{array}{c}\text { Sangat } \\
\text { Berharap }\end{array}$ & $\begin{array}{c}\text { Ber- } \\
\text { harap }\end{array}$ & $\begin{array}{c}\text { Cukup } \\
\text { Berharap }\end{array}$ & $\begin{array}{c}\text { Kurang } \\
\text { berharap }\end{array}$ & $\begin{array}{c}\text { Tidak } \\
\text { berharap }\end{array}$ & $\begin{array}{c}\text { Bobot } \\
\text { nilai }\end{array}$ \\
\hline 39 & 20 & 1 & 0 & 0 & 278 \\
\hline
\end{tabular}

Sumber: Hasil kuesioner

Keterangan angka:

$$
278=(39 \times 5)+(20 \times 4)+(1 \times 3)
$$

Tabel 12.2.

Penilaian peserta terhadap penampilan gedung yang baik

\begin{tabular}{|c|c|c|c|c|c|}
\hline $\begin{array}{c}\text { Sangat } \\
\text { puas }\end{array}$ & Puas & $\begin{array}{c}\text { Cukup } \\
\text { puas }\end{array}$ & $\begin{array}{c}\text { Kurang } \\
\text { puas B }\end{array}$ & $\begin{array}{c}\text { Tidak } \\
\text { puas }\end{array}$ & $\begin{array}{c}\text { Bobot } \\
\text { nilai }\end{array}$ \\
\hline 33 & 20 & 5 & 2 & 0 & 264 \\
\hline
\end{tabular}

Sumber: Hasil kuesioner

Keterangan angka:

$$
264=(33 \times 5)+(20 \times 4)+(5 \times 3)+(2 \times 2)
$$

2) Fasilitas ruang kelas yang menunjang kegiatan belajar mengajar

Dari 60 responden yang dianalisis telah diperoleh penilaian terhadap tingkat harapan mengenai Fasilitas ruang kelas yang menunjang kegiatan belajar mengajar, sebagaimana tertera pada tabel 13.1 sedangkan penilaian peserta mengenai Fasilitas ruang kelas yang menunjang kegiatan belajar mengajardisajikan pada tabel 13.2.
Tabel 13.1.

Tingkat harapan peserta mengenai Fasilitas kelas yang menunjang kegiatan belajar mengajar

\begin{tabular}{|c|c|c|c|c|c|}
\hline $\begin{array}{c}\text { Sangat } \\
\text { Berharap }\end{array}$ & $\begin{array}{c}\text { Ber- } \\
\text { harap }\end{array}$ & $\begin{array}{c}\text { Cukup } \\
\text { Berharap }\end{array}$ & $\begin{array}{c}\text { Kurang } \\
\text { berharap }\end{array}$ & $\begin{array}{c}\text { Tidak } \\
\text { berharap }\end{array}$ & $\begin{array}{c}\text { Bobot } \\
\text { nilai }\end{array}$ \\
\hline 43 & 17 & 0 & 0 & 0 & 283 \\
\hline
\end{tabular}

Sumber: Hasil kuesioner

Keterangan angka: $283=(43 \times 5)+(17 \times 4)$

Tabel 13.2.

Penilaian peserta terhadap Fasilitas kelas yang menunjang kegiatan belajar mengajar

\begin{tabular}{|c|c|c|c|c|c|}
\hline $\begin{array}{c}\text { Sangat } \\
\text { puas }\end{array}$ & Puas & $\begin{array}{c}\text { Cukup } \\
\text { puas }\end{array}$ & $\begin{array}{c}\text { Kurang } \\
\text { puas B }\end{array}$ & $\begin{array}{c}\text { Tidak } \\
\text { puas }\end{array}$ & $\begin{array}{c}\text { Bobot } \\
\text { nilai }\end{array}$ \\
\hline 36 & 17 & 6 & 1 & 0 & 268 \\
\hline
\end{tabular}

Sumber: Hasil kuesioner

Keterangan angka:

$$
268=(36 \times 5)+(17 \times 4)+(6 \times 3)+(1 \times 2)
$$

3) Toilet bersih dan lengkap (tissue, dll)

Dari 60 responden yang dianalisis telah diperoleh penilaian terhadap tingkat harapan mengenai Toilet bersih dan lengkap, sebagaimana tertera pada tabel 14.1 sedangkan penilaian peserta mengenai Toilet bersih dan lengkap disajikan pada tabel 14.2.

Tabel 14.1.

Tingkat harapan peserta mengenai Toilet bersih dan lengkap

\begin{tabular}{|c|c|c|c|c|c|}
\hline $\begin{array}{c}\text { Sangat } \\
\text { Berharap }\end{array}$ & $\begin{array}{c}\text { Ber- } \\
\text { harap }\end{array}$ & $\begin{array}{c}\text { Cukup } \\
\text { Berharap }\end{array}$ & $\begin{array}{c}\text { Kurang } \\
\text { berharap }\end{array}$ & $\begin{array}{c}\text { Tidak } \\
\text { berharap }\end{array}$ & $\begin{array}{c}\text { Bobot } \\
\text { nilai }\end{array}$ \\
\hline 31 & 23 & 6 & 0 & 0 & 265 \\
\hline
\end{tabular}

Sumber: Hasil kuesioner 
Keterangan angka:

$$
265=(31 \times 5)+(23 \times 4)+(6 \times 3)
$$

Tabel 14.2.

Penilaian peserta terhadap Toilet bersih dan lengkap

\begin{tabular}{|c|c|c|c|c|c|}
\hline $\begin{array}{c}\text { Sangat } \\
\text { puas }\end{array}$ & Puas & $\begin{array}{c}\text { Cukup } \\
\text { puas }\end{array}$ & $\begin{array}{c}\text { Kurang } \\
\text { puas. B }\end{array}$ & $\begin{array}{c}\text { Tidak } \\
\text { puas }\end{array}$ & $\begin{array}{c}\text { Bobot } \\
\text { nilai }\end{array}$ \\
\hline 15 & 27 & 15 & 3 & 0 & 201 \\
\hline
\end{tabular}

Sumber: Hasil kuesioner

Keterangan angka:

$$
201=(15 \times 5)+(27 \times 4)+(3 \times 3)
$$

4) Lingkungan

mendukung

kampus

pembelajaran baik.

Dari 60 responden yang dianalisis telah diperoleh penilaian terhadap tingkat harapan mengenai Lingkungan kampus mendukung suasana pembelajaran baik, sebagaimana tertera pada tabel 15.1 sedangkan penilaian peserta mengenai Lingkungan kampus mendukung suasana pembelajaran baik disajikan pada tabel 15.2.

Tabel 15.1.

Tingkat harapan peserta mengenai Lingkungan kampus mendukung suasana pembelajaran baik

\begin{tabular}{|c|c|c|c|c|c|}
\hline $\begin{array}{c}\text { Sangat } \\
\text { Berharap }\end{array}$ & $\begin{array}{c}\text { Ber- } \\
\text { harap }\end{array}$ & $\begin{array}{c}\text { Cukup } \\
\text { Berharap }\end{array}$ & $\begin{array}{c}\text { Kurang } \\
\text { berharap }\end{array}$ & $\begin{array}{c}\text { Tidak } \\
\text { berharap }\end{array}$ & $\begin{array}{c}\text { Bobot } \\
\text { nilai }\end{array}$ \\
\hline 38 & 20 & 2 & 0 & 0 & 276 \\
\hline
\end{tabular}

Sumber: Hasil kuesioner

Keterangan angka:

$$
274=(38 \times 5)+(20 \times 4)+(2 \times 3)
$$

Tabel 15.2.

Penilaian peserta terhadap Lingkungan kampus mendukung suasana pembelajaran baik

\begin{tabular}{|c|c|c|c|c|c|}
\hline $\begin{array}{c}\text { Sangat } \\
\text { puas }\end{array}$ & Puas & $\begin{array}{c}\text { Cukup } \\
\text { puas }\end{array}$ & $\begin{array}{c}\text { Kurang } \\
\text { puas. B }\end{array}$ & $\begin{array}{c}\text { Tidak } \\
\text { puas }\end{array}$ & $\begin{array}{c}\text { Bobot } \\
\text { nilai }\end{array}$ \\
\hline 24 & 28 & 6 & 2 & 0 & 254 \\
\hline
\end{tabular}

Sumber: Hasil kuesioner

Keterangan angka:

$$
254=(24 \times 5)+(28 \times 4)+(6 \times 3)+(2 \times 2)
$$

5) Fasilitas kamar yang memadai (standar)

Dari 60 responden yang dianalisis telah diperoleh penilaian terhadap tingkat harapan mengenai Fasilitas kamar yang memadai (standar), sebagaimana tertera pada tabel 16.1 sedangkan penilaian peserta mengenai Fasilitas kamar yang memadai (standar) disajikan pada tabel 16.2.

Tabel 16.1.

Tingkat harapan peserta mengenai Fasilitas kamar yang memadai (standar)

\begin{tabular}{|c|c|c|c|c|c|}
\hline $\begin{array}{c}\text { Sangat } \\
\text { Berharap }\end{array}$ & $\begin{array}{c}\text { Ber- } \\
\text { harap }\end{array}$ & $\begin{array}{c}\text { Cukup } \\
\text { Berharap }\end{array}$ & $\begin{array}{c}\text { Kurang } \\
\text { berharap }\end{array}$ & $\begin{array}{c}\text { Tidak } \\
\text { berharap }\end{array}$ & $\begin{array}{c}\text { Bobot } \\
\text { nilai }\end{array}$ \\
\hline 29 & 26 & 5 & 0 & 0 & 264 \\
\hline
\end{tabular}

Sumber: Hasil kuesioner

Keterangan angka:

$$
274=(29 \times 5)+(26 \times 4)+(5 \times 3)
$$

\section{Tabel 16.2.}

Penilaian peserta terhadap kinerja Fasilitas kamar yang memadai (standar)

\begin{tabular}{|c|c|c|c|c|c|}
\hline $\begin{array}{c}\text { Sangat } \\
\text { puas }\end{array}$ & Puas & $\begin{array}{c}\text { Cukup } \\
\text { puas }\end{array}$ & $\begin{array}{c}\text { Kurang } \\
\text { puas }\end{array}$ & $\begin{array}{c}\text { Tidak } \\
\text { puas }\end{array}$ & $\begin{array}{c}\text { Bobot } \\
\text { nilai }\end{array}$ \\
\hline 21 & 32 & 5 & 2 & 0 & 247 \\
\hline
\end{tabular}

Sumber: Hasil kuesioner

Keterangan angka:

$$
247=(21 \times 5)+(32 \times 4)+(5 \times 3)+(2 \times 2)
$$


6) Kudapan dan makan berkualitas

Dari 60 responden yang dianalisis telah diperoleh penilaian terhadap tingkat harapan mengenai Kudapan dan makan berkualitas, sebagaimana tertera pada tabel 17.1 sedangkan penilaian peserta mengenai Kudapan dan makan berkualitas disajikan pada tabel 17.2.

Tabel 17.1.

Tingkat harapan peserta mengenai Kudapan dan makan berkualitas

\begin{tabular}{|c|c|c|c|c|c|}
\hline $\begin{array}{c}\text { Sangat } \\
\text { Berharap }\end{array}$ & $\begin{array}{c}\text { Ber- } \\
\text { harap }\end{array}$ & $\begin{array}{c}\text { Cukup } \\
\text { Berharap }\end{array}$ & $\begin{array}{c}\text { Kurang } \\
\text { berharap }\end{array}$ & $\begin{array}{c}\text { Tidak } \\
\text { berharap }\end{array}$ & $\begin{array}{c}\text { Bobot } \\
\text { nilai }\end{array}$ \\
\hline 25 & 25 & 9 & 1 & 0 & 245 \\
\hline
\end{tabular}

Sumber: Hasil kuesioner

Keterangan angka:

$245=(25 \times 5)+(25 \times 4)+(9 \times 3)+(1 \times 2)$

Tabel 17.2.

Penilaian peserta terhadap Kudapan dan makan berkualitas

\begin{tabular}{|c|c|c|c|c|c|}
\hline $\begin{array}{c}\text { Sangat } \\
\text { puas }\end{array}$ & Puas & $\begin{array}{c}\text { Cukup } \\
\text { puas }\end{array}$ & $\begin{array}{c}\text { Kurang } \\
\text { puas. B }\end{array}$ & $\begin{array}{c}\text { Tidak } \\
\text { puas }\end{array}$ & $\begin{array}{c}\text { Bobot } \\
\text { nilai }\end{array}$ \\
\hline 12 & 25 & 18 & 5 & 0 & 234 \\
\hline
\end{tabular}

Sumber: Hasil kuesioner

Keterangan angka:

$234=(12 \times 5)+(25 \times 4)+(18 \times 3)+(5 \times 2)$

7) Narasumber/widyaiswara dan panitia selalu berpakaian rapih dan sopan

Dari 60 responden yang dianalisis telah diperoleh penilaian terhadap tingkat harapan mengenai Narasumber/widyaiswara dan panitia selalu berpakaian rapih dan sopan, sebagaimana tertera pada tabel 18.1 sedangkan penilaian peserta mengenai Narasumber/ widyaiswara dan panitia selalu berpakaian rapih dan sopan disajikan pada tabel 18.2.

Tabel 18.1.

Tingkat harapan peserta mengenai Narasumber/widyaiswara dan panitia selalu berpakaian rapih dan sopan

\begin{tabular}{|c|c|c|c|c|c|}
\hline $\begin{array}{c}\text { Sangat } \\
\text { Berharap }\end{array}$ & $\begin{array}{c}\text { Ber- } \\
\text { harap }\end{array}$ & $\begin{array}{c}\text { Cukup } \\
\text { Berharap }\end{array}$ & $\begin{array}{c}\text { Kurang } \\
\text { berharap }\end{array}$ & $\begin{array}{c}\text { Tidak } \\
\text { berharap }\end{array}$ & $\begin{array}{c}\text { Bobot } \\
\text { nilai }\end{array}$ \\
\hline 40 & 18 & 2 & 0 & 0 & 278 \\
\hline
\end{tabular}

Sumber: Hasil kuesioner

Keterangan angka:

$$
278=(40 \times 5)+(18 \times 4)+(2 \times 3)
$$

Tabel 18.2.

Penilaian peserta terhadap Narasumber/ widyaiswara dan panitia selalu berpakaian rapih dan sopan

\begin{tabular}{|c|c|c|c|c|c|}
\hline $\begin{array}{c}\text { Sangat } \\
\text { puas }\end{array}$ & Puas & $\begin{array}{c}\text { Cukup } \\
\text { puas }\end{array}$ & $\begin{array}{c}\text { Kurang } \\
\text { puas. B }\end{array}$ & $\begin{array}{c}\text { Tidak } \\
\text { puas }\end{array}$ & $\begin{array}{c}\text { Bobot } \\
\text { nilai }\end{array}$ \\
\hline 32 & 23 & 2 & 3 & 0 & 264 \\
\hline
\end{tabular}

Sumber: Hasil kuesioner

Keterangan angka:

$$
264=(32 \times 5)+(23 \times 4)+(2 \times 3)+(3 \times 2)
$$

\section{d. Keandalan (reliability)}

Keandalan adalah kemampuan penyelenggara diklat untuk menepati dan melaksanakan pelayanan yang dijanjikan dengan tepat dan terpercaya. Aspek ini meliputi;

1) Diklat diadakan tepat waktu

Dari 60 responden yang dianalisis telah diperoleh penilaian 
terhadap tingkat harapan mengenai Diklat diadakan tepat waktu sebagaimana tertera pada tabel 19.1 sedangkan penilaian peserta mengenai Diklat diadakan tepat waktudisajikan pada tabel 19.2.

\section{Tabel 19.1.}

Tingkat harapan peserta mengenai Diklat diadakan tepat waktu

\begin{tabular}{|c|c|c|c|c|c|}
\hline $\begin{array}{c}\text { Sangat } \\
\text { Berharap }\end{array}$ & Berharap & $\begin{array}{c}\text { Cukup } \\
\text { Berharap }\end{array}$ & $\begin{array}{c}\text { Kurang } \\
\text { berharap }\end{array}$ & $\begin{array}{c}\text { Tidak } \\
\text { berharap }\end{array}$ & $\begin{array}{c}\text { Bobot } \\
\text { nilai }\end{array}$ \\
\hline 41 & 14 & 5 & 0 & 0 & 276 \\
\hline
\end{tabular}

Sumber: Hasil kuesioner

Keterangan angka:

$$
276=(41 \times 5)+(14 \times 4)+(5 \times 3)
$$

Tabel 19.2.

Penilaian peserta terhadap Diklat diadakan tepat waktu

\begin{tabular}{|c|c|c|c|c|c|}
\hline $\begin{array}{c}\text { Sangat } \\
\text { puas }\end{array}$ & Puas & $\begin{array}{c}\text { Cukup } \\
\text { puas }\end{array}$ & $\begin{array}{c}\text { Kurang } \\
\text { puas. B }\end{array}$ & $\begin{array}{c}\text { Tidak } \\
\text { puas }\end{array}$ & $\begin{array}{c}\text { Bobot } \\
\text { nilai }\end{array}$ \\
\hline 33 & 18 & 6 & 3 & 0 & 261 \\
\hline
\end{tabular}

Sumber: Hasil kuesioner

Keterangan angka:

$261=(33 \times 5)+(18 \times 4)+(6 \times 3)+(3 \times 2)$

2) Rangkaian materi yang diberikan sesuai dengan sasaran program.

Dari 60 responden yang dianalisis telah diperoleh penilaian terhadap tingkat harapan mengenai Rangkaian materi yang diberikan sesuai dengan sasaran program, sebagaimana tertera pada tabel 20.1 sedangkan penilaian peserta mengenai Rangkaian materi yang diberikan sesuai dengan sasaran program disajikan pada tabel 20.2.
Tabel 20.1.

Tingkat harapan peserta mengenai Rangkaian materi yang diberikan sesuai dengan sasaran program

\begin{tabular}{|c|c|c|c|c|c|}
\hline $\begin{array}{c}\text { Sangat } \\
\text { Berharap }\end{array}$ & $\begin{array}{c}\text { Ber- } \\
\text { harap }\end{array}$ & $\begin{array}{c}\text { Cukup } \\
\text { Berharap }\end{array}$ & $\begin{array}{c}\text { Kurang } \\
\text { berharap }\end{array}$ & $\begin{array}{c}\text { Tidak } \\
\text { berharap }\end{array}$ & $\begin{array}{c}\text { Bobot } \\
\text { nilai }\end{array}$ \\
\hline 35 & 21 & 4 & 0 & 0 & 272 \\
\hline
\end{tabular}

Sumber: Hasil kuesioner

Keterangan angka:

$$
245=(35 \times 5)+(21 \times 4)+(4 \times 3)
$$

Tabel 20.2.

Penilaian peserta terhadap Rangkaian materi yang diberikan sesuai dengan sasaran program

\begin{tabular}{|c|c|c|c|c|c|}
\hline $\begin{array}{c}\text { Sangat } \\
\text { puas }\end{array}$ & Puas & $\begin{array}{c}\text { Cukup } \\
\text { puas }\end{array}$ & $\begin{array}{c}\text { Kurang } \\
\text { puas. B }\end{array}$ & $\begin{array}{c}\text { Tidak } \\
\text { puas }\end{array}$ & $\begin{array}{c}\text { Bobot } \\
\text { nilai }\end{array}$ \\
\hline 25 & 28 & 4 & 3 & 0 & 255 \\
\hline
\end{tabular}

Sumber: Hasil kuesioner

Keterangan angka:

$255=(25 \times 5)+(28 \times 4)+(4 \times 3)+(3 \times 2)$

3) Narasumber/widyaiswara menguasai materi diklat.

Dari 60 responden yang dianalisis telah diperoleh penilaian terhadap tingkat harapan mengenai Narasumber/ widyaiswara menguasai materi diklat, sebagaimana tertera pada tabel 21.1 sedangkan penilaian peserta mengenai Narasumber/ widyaiswara menguasai materi diklat disajikan pada tabel 21.2.

Tabel 21.1.

Tingkat harapan peserta mengenai Narasumber/widyaiswara menguasai materi diklat

\begin{tabular}{|c|c|c|c|c|c|}
\hline $\begin{array}{c}\text { Sangat } \\
\text { Berharap }\end{array}$ & $\begin{array}{c}\text { Ber- } \\
\text { harap }\end{array}$ & $\begin{array}{c}\text { Cukup } \\
\text { Berharap }\end{array}$ & $\begin{array}{c}\text { Kurang } \\
\text { berharap }\end{array}$ & $\begin{array}{c}\text { Tidak } \\
\text { berharap }\end{array}$ & $\begin{array}{c}\text { Bobot } \\
\text { nilai }\end{array}$ \\
\hline 41 & 17 & 2 & 0 & 0 & 279 \\
\hline
\end{tabular}

Sumber: Hasil kuesioner 
Keterangan angka:

$$
279=(41 \times 5)+(17 \times 4)+(2 \times 3)
$$

Tabel 21.2.

Penilaian peserta terhadap Narasumber/ widyaiswara menguasai materi diklat

\begin{tabular}{|c|c|c|c|c|c|}
\hline $\begin{array}{c}\text { Sangat } \\
\text { puas }\end{array}$ & Puas & $\begin{array}{c}\text { Cukup } \\
\text { puas }\end{array}$ & $\begin{array}{c}\text { Kurang } \\
\text { puas. B }\end{array}$ & $\begin{array}{c}\text { Tidak } \\
\text { puas }\end{array}$ & $\begin{array}{c}\text { Bobot } \\
\text { nilai }\end{array}$ \\
\hline 25 & 25 & 6 & 4 & 0 & 251 \\
\hline
\end{tabular}

Sumber: Hasil kuesioner

Keterangan angka:

$$
251=(25 \times 5)+(25 \times 4)+(6 \times 3)+(4 \times 2)
$$

\section{4) Widyaiswara mampu} presentasi/menyampaikan materi.

Dari 60 responden yang dianalisis telah diperoleh penilaian terhadap tingkat harapan mengenai Widyaiswara mampu presentasi/menyampaikan materi, sebagaimana tertera pada tabel 22.1 sedangkan penilaian peserta mengenai Widyaiswara mampu presentasi/menyampaikan materi disajikan pada tabel 22.2.

Tabel 22.1.

Tingkat harapan peserta mengenai Widyaiswara mampu presentasi/ menyampaikan materi

\begin{tabular}{|c|c|c|c|c|c|}
\hline $\begin{array}{c}\text { Sangat } \\
\text { Berharap }\end{array}$ & $\begin{array}{c}\text { Ber- } \\
\text { harap }\end{array}$ & $\begin{array}{c}\text { Cukup } \\
\text { Berharap }\end{array}$ & $\begin{array}{c}\text { Kurang } \\
\text { berharap }\end{array}$ & $\begin{array}{c}\text { Tidak } \\
\text { berharap }\end{array}$ & $\begin{array}{c}\text { Bobot } \\
\text { nilai }\end{array}$ \\
\hline 40 & 17 & 3 & 0 & 0 & 286 \\
\hline
\end{tabular}

Sumber: Hasil kuesioner

Keterangan angka:

$$
286=(25 \times 5)+(25 \times 4)+(9 \times 3)+(1 \times 2)
$$

Tabel 22.2.

Penilaian peserta terhadap Widyaiswara mampu presentasi/menyampaikan materi

\begin{tabular}{|c|c|c|c|c|c|}
\hline $\begin{array}{c}\text { Sangat } \\
\text { puas }\end{array}$ & Puas & $\begin{array}{c}\text { Cukup } \\
\text { puas }\end{array}$ & $\begin{array}{c}\text { Kurang } \\
\text { puas. B }\end{array}$ & $\begin{array}{c}\text { Tidak } \\
\text { puas }\end{array}$ & $\begin{array}{c}\text { Bobot } \\
\text { nilai }\end{array}$ \\
\hline 28 & 25 & 5 & 2 & 0 & 259 \\
\hline
\end{tabular}

Sumber: Hasil kuesioner

Keterangan angka:

$259=(12 \times 5)+(25 \times 4)+(18 \times 3)+(5 \times 2)$

5) Narasumber/widyaiswara mampu menciptakan suasana aktif dan komunikastif dalam pembelajaran

Dari 60 responden yang dianalisis telah diperoleh penilaian terhadap tingkat harapan mengenai Narasumber/widyaiswara mampu menciptakan suasana aktif dan komunikastif dalam pembelajaran, sebagaimana tertera pada tabel 23.1 sedangkan penilaian peserta mengenai Narasumber/ widyaiswara mampu menciptakan suasana aktif dan komunikastif dalam pembelajarandisajikan pada tabel 23.2.

Tabel 23.1.

Tingkat harapan peserta mengenai

Narasumber/widyaiswara mampu menciptakan suasana aktif dan komunikastif dalam pembelajaran

\begin{tabular}{|c|c|c|c|c|c|}
\hline $\begin{array}{c}\text { Sangat } \\
\text { Berharap }\end{array}$ & $\begin{array}{c}\text { Ber- } \\
\text { harap }\end{array}$ & $\begin{array}{c}\text { Cukup } \\
\text { Berharap }\end{array}$ & $\begin{array}{c}\text { Kurang } \\
\text { berharap }\end{array}$ & $\begin{array}{c}\text { Tidak } \\
\text { berharap }\end{array}$ & $\begin{array}{c}\text { Bobot } \\
\text { nilai }\end{array}$ \\
\hline 45 & 13 & 2 & 0 & 0 & 283 \\
\hline
\end{tabular}

Sumber: Hasil kuesioner

Keterangan angka:

$$
283=(45 \times 5)+(13 \times 4)+(2 \times 3)
$$


Tabel 23.2.

Penilaian peserta terhadap Narasumber/ widyaiswara mampu menciptakan suasana aktif dan komunikastif dalam pembelajaran

\begin{tabular}{|c|c|c|c|c|c|}
\hline $\begin{array}{c}\text { Sangat } \\
\text { puas }\end{array}$ & Puas & $\begin{array}{c}\text { Cukup } \\
\text { puas }\end{array}$ & $\begin{array}{c}\text { Kurang } \\
\text { puas. B }\end{array}$ & $\begin{array}{c}\text { Tidak } \\
\text { puas }\end{array}$ & $\begin{array}{c}\text { Bobot } \\
\text { nilai }\end{array}$ \\
\hline 28 & 27 & 2 & 3 & 0 & 250 \\
\hline
\end{tabular}

Sumber: Hasil kuesioner

Keterangan angka:

$250=(28 \times 5)+(27 \times 4)+(2 \times 3)+(3 \times 2)$

6) Metode belajar (diskusi, role play dll) membantu dalam mencapai sasaran diklat.

Dari 60 responden yang dianalisis telah diperoleh penilaian terhadap tingkat harapan mengenai Metode belajar (diskusi, role play dII) membantu dalam mencapai sasaran diklat sebagaimana tertera pada tabel 24.1 sedangkan penilaian peserta mengenai Metode belajar (diskusi, role play dII) membantu dalam mencapai sasaran diklat.disajikan pada tabel 24.2 .

\section{Tabel 24.1.}

Tingkat harapan peserta mengenai Metode belajar (diskusi, role play dll) membantu dalam mencapai sasaran diklat.

\begin{tabular}{|c|c|c|c|c|c|}
\hline $\begin{array}{c}\text { Sangat } \\
\text { Berharap }\end{array}$ & $\begin{array}{c}\text { Ber- } \\
\text { harap }\end{array}$ & $\begin{array}{c}\text { Cukup } \\
\text { Berharap }\end{array}$ & $\begin{array}{c}\text { Kurang } \\
\text { berharap }\end{array}$ & $\begin{array}{c}\text { Tidak } \\
\text { berharap }\end{array}$ & $\begin{array}{c}\text { Bobot } \\
\text { nilai }\end{array}$ \\
\hline 33 & 24 & 3 & 0 & 0 & 270 \\
\hline
\end{tabular}

Sumber: Hasil kuesioner

Keterangan angka:

$$
270=(33 \times 5)+(24 \times 4)+(3 \times 3)
$$

Tabel 24.2.

Penilaian peserta terhadap Metode belajar (diskusi, role play dII) membantu dalam mencapai sasaran diklat.

\begin{tabular}{|c|c|c|c|c|c|}
\hline $\begin{array}{c}\text { Sangat } \\
\text { puas }\end{array}$ & Puas & $\begin{array}{c}\text { Cukup } \\
\text { puas }\end{array}$ & $\begin{array}{c}\text { Kurang } \\
\text { puas. B }\end{array}$ & $\begin{array}{c}\text { Tidak } \\
\text { puas }\end{array}$ & $\begin{array}{c}\text { Bobot } \\
\text { nilai }\end{array}$ \\
\hline 19 & 35 & 2 & 4 & 0 & 249 \\
\hline
\end{tabular}

Sumber: Hasil kuesioner

Keterangan angka:

$249=(19 \times 5)+(35 \times 4)+(2 \times 3)+(4 \times 2)$

7) Urutan materi membantu dalam mencapai kompetensi yang diharapkan.

Dari 60 responden yang dianalisis telah diperoleh penilaian terhadap tingkat harapan mengenai Urutan materi membantu dalam mencapai kompetensi yang diharapkan, sebagaimana tertera pada tabel 25.1 sedangkan penilaian peserta mengenai Urutan materi membantu dalam mencapai kompetensi yang diharapkan disajikan pada tabel 25.2.

Tabel 25.1.

Tingkat harapan peserta mengenai Urutan materi membantu dalam mencapai kompetensi yang diharapkan

\begin{tabular}{|c|c|c|c|c|c|}
\hline $\begin{array}{c}\text { Sangat } \\
\text { Berharap }\end{array}$ & $\begin{array}{c}\text { Ber- } \\
\text { harap }\end{array}$ & $\begin{array}{c}\text { Cukup } \\
\text { Berharap }\end{array}$ & $\begin{array}{c}\text { Kurang } \\
\text { berharap }\end{array}$ & $\begin{array}{c}\text { Tidak } \\
\text { berharap }\end{array}$ & $\begin{array}{c}\text { Bobot } \\
\text { nilai }\end{array}$ \\
\hline 35 & 22 & 3 & 0 & 0 & 272 \\
\hline
\end{tabular}

Sumber: Hasil kuesioner

Keterangan angka:

$$
272=(35 \times 5)+(22 \times 4)+(3 \times 3)
$$


Tabel 25.2.

Penilaian peserta terhadap Urutan materi membantu dalam mencapai kompetensi yang diharapkan

\begin{tabular}{|c|c|c|c|c|c|}
\hline $\begin{array}{c}\text { Sangat } \\
\text { puas }\end{array}$ & Puas & $\begin{array}{c}\text { Cukup } \\
\text { puas }\end{array}$ & $\begin{array}{c}\text { Kurang } \\
\text { puas. B }\end{array}$ & $\begin{array}{c}\text { Tidak } \\
\text { puas }\end{array}$ & $\begin{array}{c}\text { Bobot } \\
\text { nilai }\end{array}$ \\
\hline 18 & 32 & 8 & 2 & 0 & 246 \\
\hline
\end{tabular}

Sumber: Hasil kuesioner

Keterangan angka:

$246=(18 \times 5)+(32 \times 4)+(8 \times 3)+(2 \times 2)$

8) Isi program dapat menambah wawasan dari kemampuan bekerja peserta.

Dari 60 responden yang dianalisis telah diperoleh penilaian terhadap tingkat harapan mengenai Isi program dapat menambah wawasan dari kemampuan bekerja peserta, sebagaimana tertera pada tabel 26.1 sedangkan penilaian peserta mengenai Isi program dapat menambah wawasan dari kemampuan bekerja peserta disajikan pada tabel 26.2.

Tabel 26.1.

Tingkat harapan peserta mengenai Isi program dapat menambah wawasan dari kemampuan bekerja peserta

\begin{tabular}{|c|c|c|c|c|c|}
\hline $\begin{array}{c}\text { Sangat } \\
\text { Berharap }\end{array}$ & $\begin{array}{c}\text { Ber- } \\
\text { harap }\end{array}$ & $\begin{array}{c}\text { Cukup } \\
\text { Berharap }\end{array}$ & $\begin{array}{c}\text { Kurang } \\
\text { berharap }\end{array}$ & $\begin{array}{c}\text { Tidak } \\
\text { berharap }\end{array}$ & $\begin{array}{c}\text { Bobot } \\
\text { nilai }\end{array}$ \\
\hline 41 & 14 & 5 & 0 & 0 & 276 \\
\hline
\end{tabular}

Sumber: Hasil kuesioner

Keterangan angka:

$$
276=(41 \times 5)+(14 \times 4)+(5 \times 3)
$$

Tabel 26.2.

Penilaian peserta terhadap Isi program dapat menambah wawasan dari kemampuan bekerja peserta

\begin{tabular}{|c|c|c|c|c|c|}
\hline $\begin{array}{c}\text { Sangat } \\
\text { puas }\end{array}$ & Puas & $\begin{array}{c}\text { Cukup } \\
\text { puas }\end{array}$ & $\begin{array}{c}\text { Kurang } \\
\text { puas. B }\end{array}$ & $\begin{array}{c}\text { Tidak } \\
\text { puas }\end{array}$ & $\begin{array}{c}\text { Bobot } \\
\text { nilai }\end{array}$ \\
\hline 27 & 23 & 6 & 4 & 0 & 243 \\
\hline
\end{tabular}

Sumber: Hasil kuesioner

Keterangan angka:

$243=(27 \times 5)+(23 \times 4)+(6 \times 3)+(4 \times 2)$

9) Kreteria penilaian dapat memacu semangat belajar dan kesiapan dalam mengikuti diklat.

Dari 60 responden yang dianalisis telah diperoleh penilaian terhadap tingkat harapan mengenai Kreteria penilaian dapat memacu semangat belajar dan kesiapan dalam mengikuti diklat, sebagaimana tertera pada tabel 27.1 sedangkan penilaian peserta mengenai Kreteria penilaian dapat memacu semangat belajar dan kesiapan dalam mengikuti diklat disajikan pada tabel 27.2.

Tabel 27.1.

Tingkat harapan peserta mengenai Kreteria penilaian dapat memacu semangat belajar dan kesiapan dalam mengikuti diklat

\begin{tabular}{|c|c|c|c|c|c|}
\hline $\begin{array}{c}\text { Sangat } \\
\text { Berharap }\end{array}$ & $\begin{array}{c}\text { Ber- } \\
\text { harap }\end{array}$ & $\begin{array}{c}\text { Cukup } \\
\text { Berharap }\end{array}$ & $\begin{array}{c}\text { Kurang } \\
\text { berharap }\end{array}$ & $\begin{array}{c}\text { Tidak } \\
\text { berharap }\end{array}$ & $\begin{array}{c}\text { Bobot } \\
\text { nilai }\end{array}$ \\
\hline 29 & 25 & 3 & 3 & 0 & 260 \\
\hline
\end{tabular}

Sumber: Hasil kuesioner

Keterangan angka:

$$
245=(29 \times 5)+(25 \times 4)+(3 \times 3)+(3 \times 2)
$$


Tabel 27.2.

Penilaian peserta terhadap Kreteria penilaian dapat memacu semangat belajar dan kesiapan dalam mengikuti diklat

\begin{tabular}{|c|c|c|c|c|c|}
\hline $\begin{array}{c}\text { Sangat } \\
\text { puas }\end{array}$ & Puas & $\begin{array}{c}\text { Cukup } \\
\text { puas }\end{array}$ & $\begin{array}{c}\text { Kurang } \\
\text { puas. B }\end{array}$ & $\begin{array}{c}\text { Tidak } \\
\text { puas }\end{array}$ & $\begin{array}{c}\text { Bobot } \\
\text { nilai }\end{array}$ \\
\hline 18 & 33 & 4 & 5 & 0 & 244 \\
\hline
\end{tabular}

Sumber: Hasil kuesioner

Keterangan angka:

$244=(18 \times 5)+(33 \times 4)+(4 \times 3)+(5 \times 2)$

\section{e. J a m i n a n / k e p a s i a n (assurance)}

Kepastian adalah pengetahuan dan kesopnan penyelenggara diklat dan kemampuannya untuk menimbulkan kepercayaan Merupakan pengetahuan dan kemampuan widyaiswara untuk menimbulkan kepercayaan dan keyakinan dari peserta. Aspek ini meliputi;

1) Bahan ajar yang diberikan membantu dalam pemahaman materi.

Dari 60 responden yang dianalisis telah diperoleh penilaian terhadap tingkat harapan mengenai Bahan ajar yang diberikan membantu dalam pemahaman materi, sebagaimana tertera pada tabel 28.1 sedangkan penilaian peserta mengenai Bahan ajar yang diberikan membantu dalam pemahaman materi disajikan pada tabel 28.2.
Tabel 28.1.

Tingkat harapan peserta mengenai Bahan ajar yang diberikan membantu dalam pemahaman materi

\begin{tabular}{|c|c|c|c|c|c|}
\hline $\begin{array}{c}\text { Sangat } \\
\text { Berharap }\end{array}$ & $\begin{array}{c}\text { Ber- } \\
\text { harap }\end{array}$ & $\begin{array}{c}\text { Cukup } \\
\text { Berharap }\end{array}$ & $\begin{array}{c}\text { Kurang } \\
\text { berharap }\end{array}$ & $\begin{array}{c}\text { Tidak } \\
\text { berharap }\end{array}$ & $\begin{array}{c}\text { Bobot } \\
\text { nilai }\end{array}$ \\
\hline 36 & 17 & 4 & 3 & 0 & 266 \\
\hline
\end{tabular}

Sumber: Hasil kuesioner

Keterangan angka:

$266=(36 \times 5)+(17 \times 4)+(4 \times 3)+(3 \times 2)$

Tabel 28.2.

Penilaian peserta terhadap Bahan ajar yang diberikan membantu dalam pemahaman materi

\begin{tabular}{|c|c|c|c|c|c|}
\hline $\begin{array}{c}\text { Sangat } \\
\text { puas }\end{array}$ & Puas & $\begin{array}{c}\text { Cukup } \\
\text { puas }\end{array}$ & $\begin{array}{c}\text { Kurang } \\
\text { puas. B }\end{array}$ & $\begin{array}{c}\text { Tidak } \\
\text { puas }\end{array}$ & $\begin{array}{c}\text { Bobot } \\
\text { nilai }\end{array}$ \\
\hline 26 & 25 & 9 & 0 & 0 & 257 \\
\hline
\end{tabular}

Sumber: Hasil kuesioner

Keterangan angka:

$257=(26 \times 5)+(25 \times 4)+(9 \times 3)$

2) Widyaiswara mampu menilai secara obyektif kepada peserta.

Dari 60 responden yang dianalisis telah diperoleh penilaian terhadap tingkat harapan mengenai Widyaiswara mampu menilai secara obyektif kepada peserta, sebagaimana tertera pada tabel 29.1 sedangkan penilaian peserta mengenai Widyaiswara mampu menilai secara obyektif kepada peserta disajikan pada tabel 29.2. 
Tabel 29.1.

Tingkat harapan peserta mengenai Widyaiswara mampu menilai secara obyektif kepada peserta

\begin{tabular}{|c|c|c|c|c|c|}
\hline $\begin{array}{c}\text { Sangat } \\
\text { Berharap }\end{array}$ & $\begin{array}{c}\text { Ber- } \\
\text { harap }\end{array}$ & $\begin{array}{c}\text { Cukup } \\
\text { Berharap }\end{array}$ & $\begin{array}{c}\text { Kurang } \\
\text { berharap }\end{array}$ & $\begin{array}{c}\text { Tidak } \\
\text { berharap }\end{array}$ & $\begin{array}{c}\text { Bobot } \\
\text { nilai }\end{array}$ \\
\hline 30 & 23 & 3 & 4 & 0 & 259 \\
\hline
\end{tabular}

Sumber: Hasil kuesioner

Keterangan angka:

$259=(30 \times 5)+(23 \times 4)+(3 \times 3)+(4 \times 2)$

Tabel 29.2.

Penilaian peserta terhadap Widyaiswara mampu menilai secara obyektif kepada peserta

\begin{tabular}{|c|c|c|c|c|c|}
\hline $\begin{array}{c}\text { Sangat } \\
\text { puas }\end{array}$ & Puas & $\begin{array}{c}\text { Cukup } \\
\text { puas }\end{array}$ & $\begin{array}{c}\text { Kurang } \\
\text { puas. B }\end{array}$ & $\begin{array}{c}\text { Tidak } \\
\text { puas }\end{array}$ & $\begin{array}{c}\text { Bobot } \\
\text { nilai }\end{array}$ \\
\hline 25 & 25 & 6 & 4 & 0 & 251 \\
\hline
\end{tabular}

Sumber: Hasil kuesioner

Keterangan angka:

$244=(25 \times 5)+(25 \times 4)+(6 \times 3)+(4 \times 2)$

3) Materi diklat sesuai dengan perkembangan (up todate)

Dari 60 responden yang dianalisis telah diperoleh penilaian terhadap tingkat harapan mengenai Materi diklat sesuai dengan perkembangan (up todate), sebagaimana tertera pada tabel 30.1 sedangkan penilaian peserta mengenai Materi diklat sesuai dengan perkembangan (up todate) disajikan pada tabel 30.2.
Tabel 30.1.

Tingkat harapan peserta mengenai Materi diklat sesuai dengan perkembangan (up todate)

\begin{tabular}{|c|c|c|c|c|c|}
\hline $\begin{array}{c}\text { Sangat } \\
\text { Berharap }\end{array}$ & $\begin{array}{c}\text { Ber- } \\
\text { harap }\end{array}$ & $\begin{array}{c}\text { Cukup } \\
\text { Berharap }\end{array}$ & $\begin{array}{c}\text { Kurang } \\
\text { berharap }\end{array}$ & $\begin{array}{c}\text { Tidak } \\
\text { berharap }\end{array}$ & $\begin{array}{c}\text { Bobot } \\
\text { nilai }\end{array}$ \\
\hline 40 & 17 & 3 & 0 & 0 & 277 \\
\hline
\end{tabular}

Sumber: Hasil kuesioner

Keterangan angka:

$$
277=(40 \times 5)+(17 \times 4)+(3 \times 3)
$$

Tabel 30.2

Penilaian peserta terhadap Materi diklat sesuai dengan perkembangan (up todate)

\begin{tabular}{|c|c|c|c|c|c|}
\hline $\begin{array}{c}\text { Sangat } \\
\text { puas }\end{array}$ & Puas & $\begin{array}{c}\text { Cukup } \\
\text { puas }\end{array}$ & $\begin{array}{c}\text { Kurang } \\
\text { puas }\end{array}$ & $\begin{array}{c}\text { Tidak } \\
\text { puas }\end{array}$ & $\begin{array}{c}\text { Bobot } \\
\text { nilai }\end{array}$ \\
\hline 26 & 26 & 4 & 4 & 0 & 244 \\
\hline
\end{tabular}

Sumber: Hasil kuesioner

Keterangan angka:

$$
244=(26 \times 5)+(26 \times 4)+(4 \times 3)+(4 \times 2)
$$

4) Materi dapat diterapkan di tempat tugas

Dari 60 responden yang dianalisis telah diperoleh penilaian terhadap tingkat harapan mengenai Materi dapat diterapkan di tempat tugas, sebagaimana tertera pada tabel 31.1 sedangkan penilaian peserta mengenai Materi dapat diterapkan di tempat tugas disajikan pada tabel 31.2.

Tabel 31.1.

Tingkat harapan peserta mengenai Materi dapat diterapkan di tempat tugas

\begin{tabular}{|c|c|c|c|c|c|}
\hline $\begin{array}{c}\text { Sangat } \\
\text { Berharap }\end{array}$ & $\begin{array}{c}\text { Ber- } \\
\text { harap }\end{array}$ & $\begin{array}{c}\text { Cukup } \\
\text { Berharap }\end{array}$ & $\begin{array}{c}\text { Kurang } \\
\text { berharap }\end{array}$ & $\begin{array}{c}\text { Tidak } \\
\text { berharap }\end{array}$ & $\begin{array}{c}\text { Bobot } \\
\text { nilai }\end{array}$ \\
\hline 43 & 16 & 5 & 0 & 0 & 284 \\
\hline
\end{tabular}

Sumber: Hasil kuesioner 
Keterangan angka:

$$
284=(43 \times 5)+(16 \times 4)+(5 \times 3)
$$

Tabel 31.2.

Penilaian peserta terhadap Materi dapat diterapkan di tempat tugas

\begin{tabular}{|c|c|c|c|c|c|}
\hline $\begin{array}{c}\text { Sangat } \\
\text { puas }\end{array}$ & Puas & $\begin{array}{c}\text { Cukup } \\
\text { puas }\end{array}$ & $\begin{array}{c}\text { Kurang } \\
\text { puas }\end{array}$ & $\begin{array}{c}\text { Tidak } \\
\text { puas }\end{array}$ & $\begin{array}{c}\text { Bobot } \\
\text { nilai }\end{array}$ \\
\hline 26 & 29 & 5 & 0 & 0 & 261 \\
\hline
\end{tabular}

Sumber: Hasil kuesioner

Keterangan angka:

$$
261=(26 \times 5)+(29 \times 4)+(5 \times 3)
$$

5) Materi mudah dipahami dan menarik.

Dari 60 responden yang dianalisis telah diperoleh penilaian terhadap tingkat harapan mengenai Materi mudah dipahami dan menarik, sebagaimana tertera pada tabel 32.1 sedangkan penilaian peserta mengenai Materi mudah dipahami dan menarik disajikan pada tabel 32.2.

\section{Tabel 32.1.}

Tingkat harapan peserta mengenai Materi mudah dipahami dan menarik

\begin{tabular}{|c|c|c|c|c|c|}
\hline $\begin{array}{c}\text { Sangat } \\
\text { Berharap }\end{array}$ & $\begin{array}{c}\text { Ber- } \\
\text { harap }\end{array}$ & $\begin{array}{c}\text { Cukup } \\
\text { Berharap }\end{array}$ & $\begin{array}{c}\text { Kurang } \\
\text { berharap }\end{array}$ & $\begin{array}{c}\text { Tidak } \\
\text { berharap }\end{array}$ & $\begin{array}{c}\text { Bobot } \\
\text { nilai }\end{array}$ \\
\hline 38 & 22 & 0 & 0 & 0 & 278 \\
\hline
\end{tabular}

Sumber: Hasil kuesioner

Keterangan angka:

$$
278=(38 \times 5)+(22 \times 4)
$$

Tabel 32.2.

Penilaian peserta terhadap Materi mudah dipahami dan menarik

\begin{tabular}{|c|c|c|c|c|c|}
\hline $\begin{array}{c}\text { Sangat } \\
\text { puas }\end{array}$ & Puas & $\begin{array}{c}\text { Cukup } \\
\text { puas }\end{array}$ & $\begin{array}{c}\text { Kurang } \\
\text { puas }\end{array}$ & $\begin{array}{c}\text { Tidak } \\
\text { puas }\end{array}$ & $\begin{array}{c}\text { Bobot } \\
\text { nilai }\end{array}$ \\
\hline 26 & 25 & 5 & 4 & 0 & 253 \\
\hline
\end{tabular}

Sumber: Hasil kuesioner
Keterangan angka:

$253=(26 \times 5)+(25 \times 4)+(5 \times 3)+(4 \times 2)$

\section{Persepsi Tingkat Harapan dan Kepuasan terhadap Kualitas Pelayanan Penyelenggaraan Diklat}

Dari hasil penelitian tingkat harapan dan kepuasan peserta dapat disusun suatu tingkat kesesuaian sebagaimana telah diuraikan pada landasan teori diatas. Tingkat kesesuaian ini bertujuan untuk mengetahui urutan prioritas factor-faktor yang mempengaruhi kepuasan peserta. Hasil perhitungan kuesioner mengenai tingkat harapan dan kepuasan peserta, telah diperoleh data seperti table 13.1. dan hasil perhitungan tingkat kesesuaian disajikan pada table 13.2

\section{a. Hasil Penelitian Tingkat Harapan Peserta}

Jika dilihat dari dari tingkat harapan peserta (lihat tabel 33.4) di atas, maka terdapat peringkat (rangking) yang mereka harapan dapat mereka terima/inginkan adalah sebagai berikut;

Pertama : variabel Keandalan, dengan nilai rata-rata 2,75;

Kedua : variabel Jaminan, dengan nilai rata-rata 2,73;

Ketiga : variabel Bukti fisik, dengan nilai rata-rata 2,70; 
Keempat : variabel Kesigapan, dengan nilai rata-rata 2,69;

Kelima : variabel empati, dengan nilai rata-rata 2,66 .

Dari peringkat tersebut, maka terlihat bahwa peserta dalam memilih sebuah kualitas pelayanan penyelenggaraan diklat, lebih memilih variabel keandalan, yakni kemampuan penyelenggaraan diklat untuk menepati janji dengan tepat dan terpercaya bagi peserta (Diklat diadakan tepat waktu, Rangkaian materi yang diberikan sesuai dengan sasaran program, narasumber/ widyaiswara menguasai materi diklat, Widyaiswara mampu dalam presentasi/menyampaikan materi, narasumber/widyaiswara mampu menciptakan suasana aktif dan komunikatif dalam pembelajaran.

Metode belajar (diskusi, role play, dll) membantu dalam mencapai sasaran diklat, Urutan materi membantu dalam mencapai kompetnesi yang diharapkan, Isi program pelatihan dapat menambah wawasan dari kemampuan bekerja peserta, Kriteria penilaian dapat memacu semangat belajar dan kesiapan dalam mengikuti diklat). Dan variabel Jaminan yakni Pengetahuan dan kemampuan widyaiswara untuk menimbulkan kepercayaan dan keyakinan dari peserta (Bahan ajar yang diberikan membantu dalam pemahaman materi, widyaiswara mampu menilai secara obyektif kepada peserta, Materi diklat sesuai dengan perkembangan (up to date), Materi dapat diterapkan, Materi mudah dipahami dan menarik).

Sedangkan variabel empati, yakni perhatian dari penyelenggara diklat yang bersifat pribadi kepada peserta (Kemampuan panitia, narasumber/widyaiswara dan Petugas berkomunikasi dengan peserta petugas berkomunikasi dengan peserta, informasi yang jelas mengenai jadwal pelaksanaan diklat jadwal pelaksanaan diklat, Informasi yang jelas mengenai peraturan dalam diklat, Informasi yang jelas mengenai fasilitas peserta, Informasi program yang diberikan membantu dalam kesiapan mengikuti diklat, widyaiswara memberikan motivasi kepada peserta diklat) merupakan prioritas terakhir.

Karena itu, maka yang diinginkan peserta dalam memilih sebuah penyelenggaraan diklat adalah faktor kemampuan penyelenggara diklat untuk menepati janji dan melaksanakan pelayanan yang dijanjikan dengan tepat dan terpercaya. Hal ini akan memberikan dampak karakteristik layanan bahwa layanan yang diberikan akan bertahan lama

\section{b. Tingkat Kepuasan Peserta}

Dalam hal kinerja yang ditunjukan penyelenggara diklat, dari kelima derminan kualitas 
pelayanan yang mereka terima dapat diurutkan sesuai dengan nilai tertinggi sebagai berikut;

Pertama : variabel Keandalan, dengan nilai rata-rata 2,95;

Kedua : variabel Jaminan, dengan nilai rata-rata 2,74;

Ketiga : variabel Empati, dengan nilai rata-rata 2,51 ;

Keempat: variabel tangible, dengan nilai rata-rata 2,47;

Kelima : variabel Kesigapan, dengan nilai rata-rata 1,10

Jika dilhat hasil kinerja penyelenggaraan diklat seperti yang tertera Tingkat Kepuasan peserta, maka terlihat hasil perhitungan rata-rata yang diperoleh adalah berada di antara 1,10 sampai dengan 2,95 , dengan demikian secara keseluruhan dapat dikatakan bahwa kinerja yang diberikan pihak penyelenggara diklat sudah sesuai dengan tingkat prioritas harapan peserta.

\section{c. Tingkat Kesesuaian Penilaian Harapan dan Kepuasan Peserta}

Jika dibandingkan antara kinerja penyelenggaraan diklat dengan harapan peserta diperoleh tingkat kesesuaian yang dapat diurutkan sesuai dengan persentase tertinggi sebagai berikut;

Pertama : variabel Empati, dengan nilai rata-rata 94,53\%;

Kedua : variabel Bukti fisik, dengan nilai rata-rata 91,75\%;

Ketiga : variabel Keandalan, dengan nilai rata-rata 91,09\%;

Keempat : variabel Jaminan, dengan nilai rata-rata 90,74\%;

Kelima : variabel Kesigapan, dengan nilai rata-rata $74,10 \%$.

Dari data di atas, maka terlihat bahwa tingkat kesesuaian antara kinerja yang ditunjukkan oleh penyelenggara diklat dengan harapan peserta berada di antara $74,10 \%$ sampai dengan $94,53 \%$, jika dilihat dari tingkat harapan peserta dan tingkat kinerja penyelenggaraan diklat yang lebih utama adalah mengnai variable keandalan, padahal ditingkat kesesuaian berada pada prioritas ketiga. Dengan demikian bila dilihat dari tingkat harapan dan kepuasan peserta terjadi ketidaksesuaian, dimana harapan dan kepuasan berada pada variabel keandalan, sedangkan pada tingkat kesesuaiannya berada pada variabel empati (perioritas pertama). 


\section{d. Urutan Prioritas Kualitas Pelayanan Penyelenggaraan Diklat Pusdiklat}

Analisiskepentingan dan kinerja (Importance Performance Analysis) dapat digunakan untuk merangking berbagai unsur dari kumpulan layanan serta mengidentifikasi tindakan apa yang diperlukan oleh pihak penyelenggaraan diklat. Dari ke 32 (tiga puluh dua) unsur yang mempengaruhi peserta dalam memilih kualitas layanan penyelenggara diklat tersebut dibagi empat bagian. Untuk mengetahui usaha-usaha perbaikan mutu/kualitas pelayanan yang utama harus dilakukan dalam jangka pendek, dapat diketahui dengan menggunakan diagram kartesius, berikut ini:

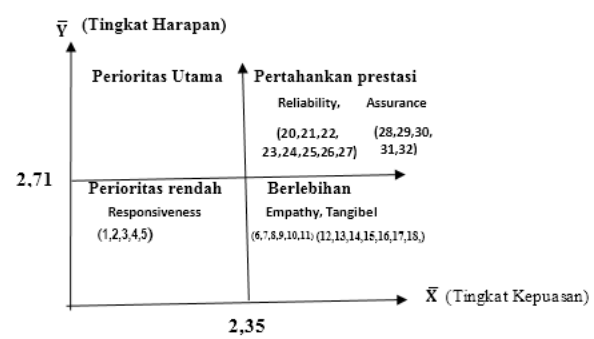

Diagram 2. Diagram Kartesius (hasil)

Pada diagaram kartesius secara umum, unsur-unsur yang mempengaruhi dalam memilih kualitas layanan pelenyelenggaraan diklat berada pada kuadran B dan kuadran $C_{\text {; }}$ berarti menjadi tugas penyelenggaraan diklat untuk berkonsentrasi demi mempertahankan prestasi yang sudah ada, terutama unsur yang terdapat pada kudaran C (sumber lihat diagram 2). Pada diagram kartesius (gambar 3) tersebut, maka dapat dianalisis bahwa ada 5 (lima) unsur layanan yang dianggap penting oleh peserta, tapi kurang mendapat perhatian pihak penyelenggara diklat (pada unsur kuadran C) sehingga peserta kurang puas (tingkat kepuasan dibawah rata-rata).

Unsur-unsur adalah sebagai berikut:

1) Unsur 1 : Kemudahan menghubungi Pusdiklat Tenaga Teknis mengenai informasi diklat;

2) Unsur 2 : Keramahan, perhatian dan kesopanan panitia, widyaiswara beserta petugas

3) Unsur 3 : Kecepatan panitia/petugas/widyaiswa/ narasumber dalam menangani keluhan peserta

4) Unsur 4 : Narasumber/ Widyaiswara disiplin dan bertanggung jawab terhadap pelatihan

5) Unsur 5 : Informasi adanya diklat diberikan 1 minggu sebelum pe-laksanaan diklat

6) Di lain hal pada diagram kartesius (gambar 3) menurut peserta juga terdapat unsur layanan minor yang dilaksanakan dengan baik, padahal tidak berharap (tidak penting) menurut peserta, suatu yang sangat berlebihan 
(kudaran D), unsur itu adalah:

7) Unsur 6 : Kemampuan panitia, narasumber/ widyaiswara dan Petugas berkomunikasi dengan peserta petugas berkomunikasi dengan peserta

8) Unsur 7 :Informasiyangjelas mengenai jadwal pelaksanaan diklat jadwal pelaksanaan diklat

9) Unsur 8 : Informasi yang jelas mengenai peraturan dalam diklat

10) Unsur 9 : Informasi yang jelas mengenai fasilitas peserta

11) Unsur 10 : Informasi program yang diberikan membantu dalam kesiapan mengikuti diklat

12) Unsur 11 : Widyaiswara memberikan motivasi kepada peserta diklat

13) Unsur 12 : Fisik tampilan gedung diklat baik;

14) Unsur 13 : Fasilitas ruang kelas menunjang kegiatan belajar mengajar;

15) Unsur 14 : Toilet bersih dan lengkap (tissue, dIl)

16) Unsur 15 : Lingkungan kampus mendukung suasana pembelajaran baik;

17) Unsur 16 : Fasilitas kamar memadai;

18) Unsur 17 : Kudapan dan makanan berkualitas;
19) Unsur18 : Narasumber/ Widyaisawara dan panitia selalu berpakaian rapi sopan

\section{Pembahasan}

Dengan berlandaskan hasil penelitian di atas maka dapat dianalisis dari masing-masing dimensi layanan seperti berikut:

\section{a. Responsiveness (Kesigapan/ ketanggapan)}

Dimensi responsiveness pada diagram kartesius terdapat pada kuadran C, berarti variabel responsiveness (kesigapan) menunjukkan faktor-faktor yang dianggap kurang penting/berharap oleh peserta, pelaksanaannya di jalankan secara cukup atau biasabiasa saja dengan nilai rata-rata tingkat kepuasan 1,10 dan tingkat harapan nilai rata-rata 2,69. Hal ini berarti bahwa kemudahan menghubungi Pusdiklat Tenaga Teknis mengenai informasi diklat, keramahan, perhatian dan kesopanan panitia, widyaiswara beserta petugas, kecepatan panitia/ petugas/widyaiswara/narasumber dalam menangai keluhan peserta, narasumber/widyaiswara disiplin dan bertanggung jawab terhadap pelatihan, informasi adanya diklat diberikan 1 minggu sebelum pelaksanaan diklat, menurut peserta kurang penting dan pelaksanaannya cukup atau biasabiasa saja.

\section{b. Empathy (empati)}

Dimensi empathy ini pada 
diagram kartesius (gambar 3) terdapat pada kuadran $D$, berarti faktor-faktor yang kurang penting/ berharap tetapi pelaksanaannya berlebihan dengan nilai rata-rata tingkat kepuasan 2,51, dan nilai rata-rata tingkat harapan 2,66. Hal ini berarti bahwa kemampuan pantia, narasumber/widyaiswara dan petugas berkomunikasi dengan peserta, informasi yang jelas mengenai jadwal pelaksanaan diklat, informasi yang jelas mengenai fasilitas peserta, informasi program yang diberikan membantu dalam kesiapan mengikuti diklat, informasi yang jelas mengenai peraturan dalam diklat, widyaiswara memberikan motivasi kepada peserta diklat, menurut peserta adalah faktorfaktor yang kurang penting/ berharap tetapi pelaksanaannya berlebihan.

\section{c. Tangible (Bukti fisik)}

Dimensi tangible pada diagram kartesius (gambar 3) terdapat pada kuadran D, berarti faktor-faktor yang kurang penting/ berharap tetapi pelaksanaannya berlebihan, dengan nilai rata-rata tingkat kepuasan 2,47, dan nilai rata-rata tingkat harapan 2,70, hal ini berarti bahwa Widyaiswara memberikan motivasi kepada peserta diklat, Fisik tampilan gedung diklat baik, Fasilitas ruang kelas menunjang kegiatan belajar mengajar, Toilet bersih dan lengkap (tissue, dll), Lingkungan kampus mendukung suasana pembelajaran baik, fasilitas kamar memadai, kudapan dan makanan berkualitas, narasumber/ widyaisawara dan panitia selalu berpakaian rapi dan sopan. Menurut peserta faktorfaktor tersebut kurang penting akan tetapi penyelenggaraan diklat melaksanakan berlebihan.

\section{d. Reliability (Keandalan)}

Dimensi reliability ini dalam diagram kartesius (gambar 3) terdapat pada kuadran B, berarti variabel ini menunjukkan faktorfaktor yang dianggap sangat penting/berharap, telah berhasil dilaksanakan sesuai dengan keinginan/harapan peserta dan sangat memuaskan sehingga wajib dipertahankan, dengan nilai ratarata tingkat kepuasan 2,95, dan nilai rata-rata tingkat harapan 2,75 . Hal ini berarti bahwa Diklat diadakan tepat waktu, Rangkaian materi yang diberikan sesuai dengan sasaran program, Widyaiswara mampu dalam presentasi/ menyampaikan materi, narasumber/widyaiswara mampu menciptakan suasana aktif dan komunikatif dalam pembelajaran, Metode belajar (diskusi, role play, dII) membantu dalam mencapai sasaran diklat, Urutan materi membantu dalam mencapai kompetnesi yang diharapkan, isi program pelatihan dapat menambah wawasan dari kemampuan bekerja peserta, Kriteria penilaian dapat memacu semangat belajar dan kesiapan dalam mengikuti diklat, factorfaktor ini menurut peserta sangat 
penting dan sudah dilaksanakan sesuai dengan keinginan/harapan atau sangat memuaskan. Maka variabel ini harus dipertahankan.

\section{e. Assurance (Jaminan)}

Dimensi assurance ini pada diagram kartesius (gambar 3) terdapat pada kuadran B, berarti assurance menunjukkan faktorfaktor yang dianggap sangat penting oleh peserta. Dimensi ini telah berhasil dilaksanakan sesuai dengan keinginan/harapan peserta dan sangat memuaskan sehingga harus dipertahankan dengan nilai rata-rata tingkat kepuasan 2,74 , dan nilai rata-rata tingkat harapan 2,73. Hal ini berarti bahwa bahan ajar yang diberikan membantu dalam pemahaman materi, widyaiswara mampu menilai secara objektif kepada peserta, materi diklat sesuai dengan perkembangan (up to date), materi dapat diterapkan, materi mudah dipahami dan menarik. Berarti faktor-faktor ini dianggap sangat penting oleh peserta, dan oleh penelenggaraan diklat telah dilaksanakan sesuai dengan harapan peserta dan sangat baik. Oleh karena itu faktor-faktor ini harus dipertahankan.

\section{PENUTUP}

\section{A. Simpulan}

Berdasar hasil pengolahan data serta analisis pembahasan tersebut, yang berkaitan dengan unsur-unsur yang mempengaruhi kualitas pelaksanaan pelayanan Pendidikan dan Pelatihan Guru IPS Tingkat Madya Pusdiklat Tenaga Teknis Pendidikan dan Keagamaan, dan untuk menjawab tujuan dan rumusan masalah tersebut, maka dapat ditarik simpulan sebagai berikut:

1. Penilaian peserta mengenai kualitas pelayanan yang diberikan terhadap penyelenggaraan diklat sebagai berikut:

a) Bahwa pada umumnya peserta puas sampai dengan amat puas. Akan tetapi, dalam pelaksanaan kualitas pelayanan penyelenggaraan diklat belum memenuhi skala perioritas harapan peserta karena ada perbedaan antara tingkat kesesuaian dengan tingkat harapan dan tingkat kepuasan, dimana faktorfaktor penentu kepuasan dari kualitas pelayanan berada pada variabel reliablity, dan assurance, sedangkan pada tingkat kesesuian berada pada variabel empathy, dan tangible.

b) Bahwa masih perlu peningkatan kinerja penyelenggara diklat pada variabel Responsiveness (kesigapan), agar variabel ini dapat minimal sejajar atau lebih tinggi dengan variabel yang lain.

2. Faktor-faktor yang menjadi penentu tingkat harapan dan 
kepuasan pada diklat teknis fungsional guru IPS tingkat madya, adalah:

a) Faktor kemampuan penyelenggaraan diklat untuk menepati janji dengan tepat dan terpercaya bagi peserta (variabel Keandalan/ Reliability);

b) Faktor Pengetahuan dan kemampuan widyaiswara untuk menimbulkan kepercayaan dan keyakinan dari peserta (variabel jaminan/ assurance).

\section{B. Saran}

Berdasar analisis pembahasan dankesimpulandiatas, maka peneliti mencoba untuk mengemukakan beberapa rekomendasi yang mungkin dapat dipertimbangkan oleh pihak pengambil kebijakan pada penyelenggaraan diklat sebagai alternatif dalam upaya meningkatkan mutu, yaitu sebagai berikut :

a. Untuk mempertahankan variabel reliability (keandalan) dan variabel assurance (jaminan) pihak penyelenggara diklat (Pusdiklat) perlu selalu meningkatkan kemampuan penyelenggaraan diklat untuk menepati janji dengan tepat dan terpercaya bagi peserta, pengetahuan dan kemampuan widyaiswara untuk menimbulkan kepercayaan dan keyakinan dari peserta dengan jalan melakukan pengembangan terhadap pejabat eselon III dan IV, widyaiswara maupun jabatan umum lainnya secara berkesinambungan baik formal maupun informal.

b. Merupakan tugas dari penyelenggara diklat (Pusdiklat) untuk meningkatkan kinerjanya yang sudah baik, yang selama ini berada di antara 1,10 sampai dengan 2,95, agar dapat mencapai nilai 4,5 sampai dengan 5 ; dengan cara meningkatkan motivasi kerja karyawan melalui pemberian penghargaan, maupun biaya siswa bagi yang mengembangkan pendidikan yang lebih tinggi atau pelatihan yang berkenaan dengan tugas dan fungsinya.

c. Dalam jangka pendek, peneyelenggara diklat (Pusdiklat) harus lebih memprioritaskan peningkatan kinerjanya dalam kesigapan yaitu kemauan untuk membantu peserta dan memberikan pelayanan dengan cepat. Hal ini dapat diatasi dengan pengarahan dan motivasi serta kontrol yang ketat dari supervisi maupun manajemen. 


\section{DAFTAR PUSTAKA}

Adi, Albertus FR. 2012. "Analisis Pengaruh Harga, Kualitas Produk, Dan Kualitas Layanan Terhadap Kepuasan Pelanggan (Studi Pada Waroeng Spesial Sambal Cabang Lampersari Semarang)". Program Sarjana Fakultas Ekonomika Dan Bisnis Universitas Diponegoro Semarang.

Aditya, Tjiptjono. 2011. Pengaruh Kualitas Pelayanan dan Kualitas Produk Terhadap Keputusan Pembelian. Program Studi Ekonomi dan Manajemen Fakultas Ekonomi dan Bisnis Universitas Muhammadiyah Surakarta.

Arikunto, Suharsimi. 2010. Prosedur Penelitian Suatu Pendekatan Praktik. Jakarta: Rineka Cipta

Kartini, Kartono. 1993. "Psikologi Industri. Jakarta: Pustaka Pelajar.

Kotler dan Keller. 2009. Pengaruh Kepuasan atas Kualitas Pelayanan dan Kepercayaan terhadap Loyalitas Nasabah PT. BANK MANDIRI Tbk Cabang Muaro Padang. Jurnal. Padang. Fakultas Ekonomi Negeri Padang.

Kotler, Philip dan Gary Armstrong. 2012. Prinsip-prinsip Pemasaran. Edisi 13. Jilid 1. Jakarta: Erlangga.

Lovelock, Chirstoper dan Jochen Wirtz. 2011. Service Marketing. New Jersey USA: Pearson.

Miftah Toha. 1994. "Manajemen Sumber Daya Manusia Dalam Organisasi". Jakarta: Pustaka Pelajar.

Parasuraman, A, Valerie A. Zeithaml, Leonard L. Berry. 1998 SERVQUA: A Multiple Item Scale For Measuring Consumer Perception Of Service Quality. Journal of Retailing Vol. 64 No. 1, pp 12-37.

Prahastuti, L. 2011. Analisis Pengaruh Kualitas Layanan, Kualitas Produk terhadap Kepuasan Konsumen untuk meningkatkan Loyalitas Konsumen Indosat (Studi Pada Pelanggan Indosat di Wilayah Semarang). Fakultas Ekonomi Universitas Diponegoro Semarang.

Putra, FTB. 2012. Analisis pengaruh Kualitas Pelayanan, Harga, dan Kepuasan Pelanggan terhadap Loyalitas (Studi pada bengkel mobil rapiglass autocare Semarang). Fakultas Ekonomi Universitas Diponegoro Semarang.

Sugiyono. 2009. Metode Penelitian Bisnis (Pendekatan Kuantitatif, Kualitatif, dan R\&D). Bandung: Alfabeta 
Sukmawati, K. 2011. Pengaruh Kualitas Layanan, Harga, dan Kepuasan Pelanggan terhadap Loyalitas Pelanggan Jasa Transportasi Kereta Api Eksekutif. Jurnal Manajemen hal 1-16, Depok FE Universitas Guna Dharma.

Sulartiningtyas, Sri. 2006. "Analisis Kepentingan dan Knerja Sekolah MAN I Tangerang, Penelitian IImiah, Tesis STIE IPWIJA". Jakarta.

Supranto, J., 1994. "Kumpulan Tulisan Populer Tentang Ekonomi Manajemen Pemasaran Berwawasan Global". BP. IPWIJA. Jakarta. 1997. "Metode Riset dan Aplikasinya dalam Pemasaran". Jakarta: Rineka Cipta.

2004. "Proposal Penelitian dan Contoh", Jakarta: UIP.

Tjiptono, Fandy. 2008. Strategi Pemasaran. Edisi 3. Yogyakarta: Andi.

Ujang Sumarwan. 2004. Perilaku Teori dan Penerapannya dalam Pemaasaran. Bogor: Ghalia Indonesia

Widoyoko, Eko Putro. 2012. Teknik Penyusunan Instrumen Penelitian. Yogyakarta: Rineka Cipta.

Wiradi. 2006. Analisis Sosial. Bandung: Yayasan AKATIGA

Zeithaml, V. Parasuraman, A. and L. Berry L. 1985. "Problems and Strategies in Services Marketing". Jurnal of Marketing Vol. 49. (Spring). 